Provided for non-commercial research and education use. Not for reproduction, distribution or commercial use.

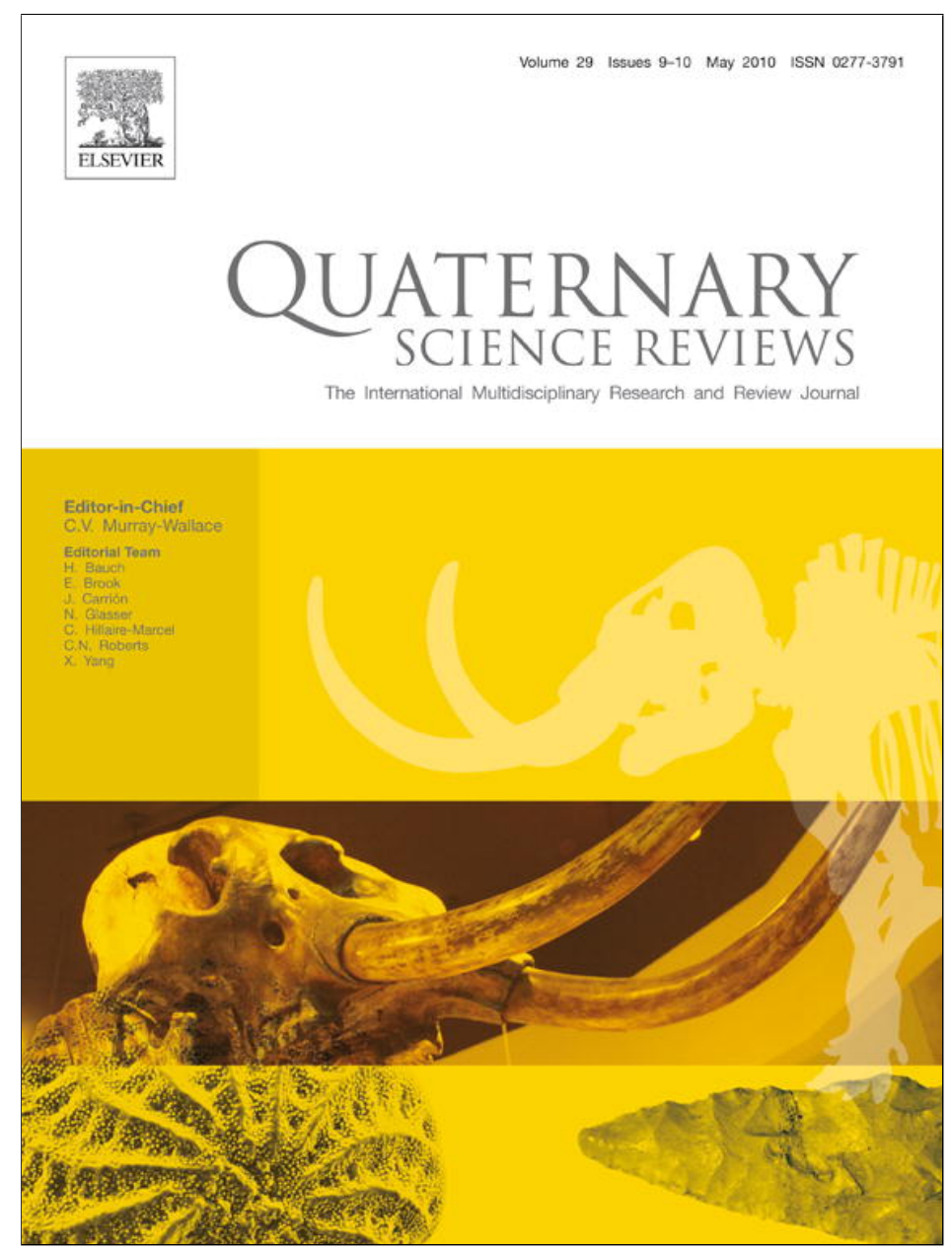

This article appeared in a journal published by Elsevier. The attached copy is furnished to the author for internal non-commercial research and education use, including for instruction at the authors institution and sharing with colleagues.

Other uses, including reproduction and distribution, or selling or licensing copies, or posting to personal, institutional or third party websites are prohibited.

In most cases authors are permitted to post their version of the article (e.g. in Word or Tex form) to their personal website or institutional repository. Authors requiring further information regarding Elsevier's archiving and manuscript policies are encouraged to visit:

http://www.elsevier.com/copyright 


\title{
Late Quaternary floods and droughts in the Nile valley, Sudan: new evidence from optically stimulated luminescence and AMS radiocarbon dating
}

\author{
M.A.J. Williams ${ }^{a}$, ${ }^{\text {, F.M. Williams }}{ }^{b}$, G.A.T. Duller ${ }^{c}$, R.N. Munro ${ }^{d}$, O.A.M. El Tom ${ }^{\text {e }}$, T.T. Barrows ${ }^{f}$, \\ M. Macklin ${ }^{\mathrm{c}}$, J. Woodward ${ }^{\mathrm{g}}$, M.R. Talbot ${ }^{\mathrm{h}, 1}$, D. Haberlah ${ }^{\mathrm{i}}$, J. Fluin $^{\mathrm{j}}$ \\ ${ }^{a}$ Geographical and Environmental Studies, University of Adelaide, Adelaide, SA 5005, Australia \\ ${ }^{\mathrm{b}}$ Luminescence Dating Laboratory, School of Chemistry and Physics, University of Adelaide, Adelaide, 5005, Australia \\ ${ }^{\mathrm{c}}$ Institute of Geography and Earth Sciences, University of Aberystwyth, Aberystwyth, Ceredigion SY23 3DB, UK \\ ${ }^{\mathrm{d}}$ Old Abbey Associates, Tarbet Court, Dirleton, East Lothian, Scotland EH39 5DX, UK \\ ${ }^{\mathrm{e}}$ Land \& Water Research Center, Agricultural Research E Technology Corporation P.O. Box 216, Wad Medani, Sudan \\ ${ }^{\mathrm{f}}$ School of Geography, The University of Exeter, Exeter, Devon, EX4 4RJ, UK \\ ${ }^{\mathrm{g}}$ School of Environment and Development, University of Manchester, Manchester, UK \\ ${ }^{\mathrm{h}}$ Geological Institute, University of Bergen, 5007 Bergen, Norway \\ ${ }^{\mathrm{i}}$ Australian School of Petroleum, University of Adelaide, Adelaide 50005, Australia \\ ${ }^{\mathrm{j}}$ Earth and Environmental Science, University of Adelaide, Adelaide 5005, Australia
}

\section{A R T I C L E I N F O}

\section{Article history:}

Received 15 October 2009

Received in revised form

1 February 2010

Accepted 11 February 2010

\begin{abstract}
A B S T R A C T
Our results show that the late Pleistocene Nile in northern Sudan was shifting position and actively aggrading at $145 \pm 20 \mathrm{kyr}, 83 \pm 24 \mathrm{kyr}, 32 \pm 8 \mathrm{kyr}$ and $20.7 \pm 0.2 \mathrm{kyr}$ and indicate, for the first time, a phase of high-energy flow in the White Nile at $27.8 \pm 3.2 \mathrm{kyr}$, with still high but somewhat reduced flow in that river at $13.3 \mathrm{kyr}, 10 \mathrm{kyr}$ and 4.8-4.0 kyr. Beach ridges associated with a $386 \mathrm{~m}$ strandline of the White Nile have OSL ages of $27.5 \pm 2.7 \mathrm{kyr}$ and $14.5 \pm 1.6 \mathrm{kyr}$. The Holocene terraces and former channels of the main Nile have ages of $11 \mathrm{kyr}, 6.5-5.0 \mathrm{kyr}$ and $4.8-4.0 \mathrm{kyr}$, after which there was a general decline in flood discharge. The now arid main Nile valley in northern Sudan was significantly wetter during the early to middle Holocene, with a lake up to $450 \mathrm{~km}^{2}$ in area, fed by an overflow channel from the early Holocene Nile between $9.5 \mathrm{kyr}$ and $7.5 \mathrm{kyr}$. Previously stable late Pleistocene dunes were reactivated at intervals during the Holocene, with five samples from the White Nile valley indicating brief phases of Holocene dune activity at $9.9 \pm 2.0 \mathrm{kyr}, 9.0 \pm 2.8 \mathrm{kyr}, 6.6 \pm 0.9 \mathrm{kyr}, 4.8 \pm 0.9 \mathrm{kyr}$ and $2.9 \pm 0.5 \mathrm{kyr}$, the earliest of which occurred within periods of generally wetter climate and higher Nile flow. The youngest freshwater shells on the Khor Abu Habl alluvial fan west of the White Nile correspond to a time of regionally wetter climate between 1.7 and 1.0 kyr. Our results suggest that millennial scale climatic instability may have been characteristic of Holocene climates in this region.
\end{abstract}

(c) 2010 Elsevier Ltd. All rights reserved.

\section{Introduction}

\subsection{Background to this study}

Understanding the effects of past climatic changes on the world's great river systems, the lifeblood of civilisations ancient and modern, is essential to an understanding of how these systems may respond to future change. As it passes through Sudan and Egypt, the river Nile has long provided a corridor for human migration through arid northern Africa, connecting central and eastern Africa with the

\footnotetext{
* Corresponding author. Tel.: +61 88303 4170; fax: +61 883033772. E-mail address: martin.williams@adelaide.edu.au (M.A.J. Williams). 1 Deceased.
}

Mediterranean. Obtaining a robust chronology of major changes in the flow regime is important for interpreting the role that the Nile corridor may have played in human dispersals through the Quaternary. The work reported here is part of a wider and ongoing investigation of the Quaternary evolution of the Nile basin (Williams, 1966, 2009; Adamson et al., 1980, 1982; Williams and Adamson, 1980; Talbot et al., 2000; Woodward et al., 2001, 2007; Krom et al., 2002; Welsby et al., 2002; Williams et al., 2006; Talbot and Williams, 2009; Williams and Talbot, 2009) which aims to reconstruct the environmental history of the Nile, the longest river in the world, from upland source to marine sink (Fig. 1), over the past 30000 years for which a reliable radiocarbon chronology is possible.

Marine sediment cores collected from the floor of the eastern Mediterranean show a repetitive depositional sequence of alternating dark, organic-rich sediments (known as sapropels) and 


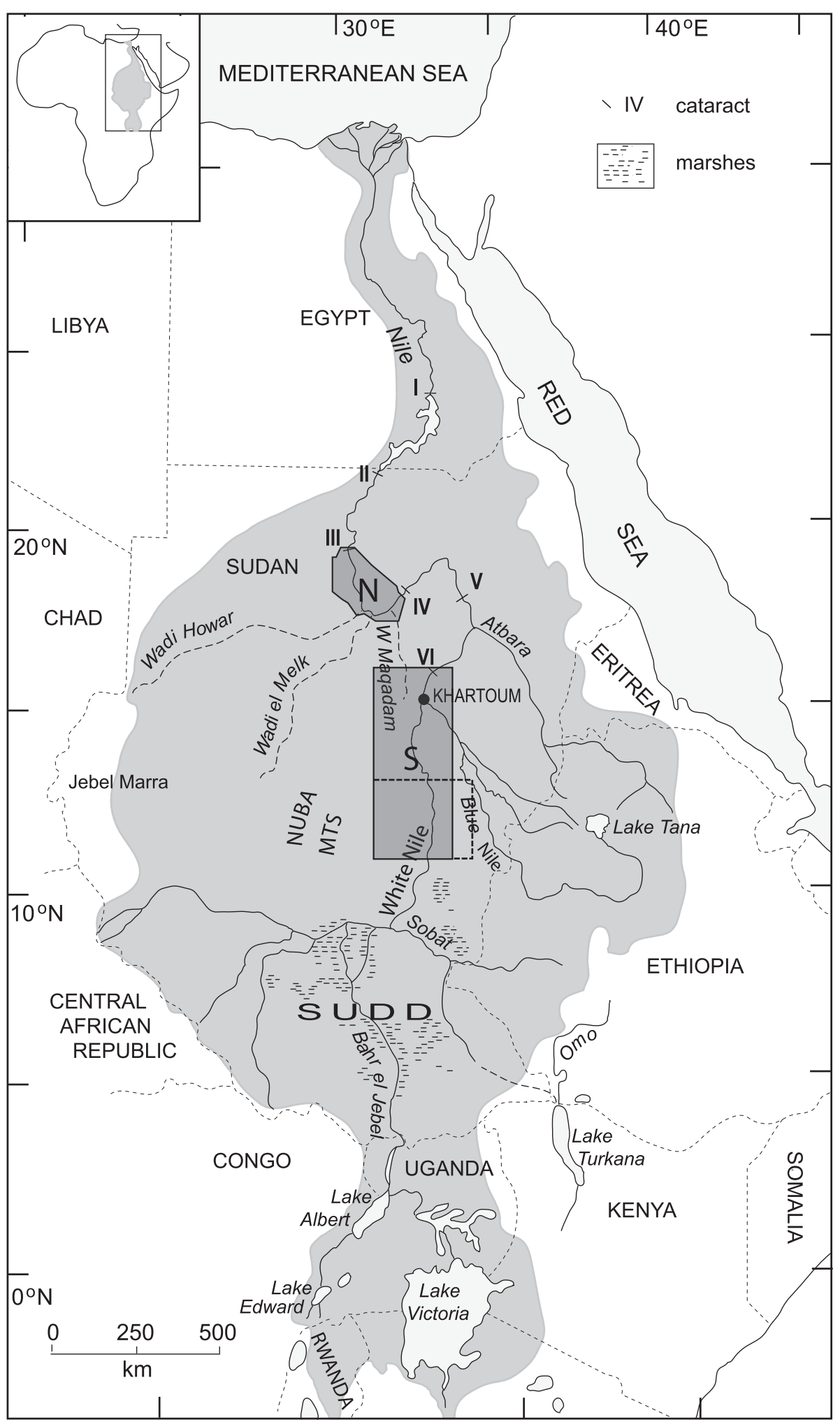

Fig. 1. The Nile basin showing location of the northern and southern areas investigated.

calcareous muds with a significant content of Saharan wind-blown dust (Rossignol-Strick et al., 1982; Larrasoaňa et al., 2003; Ducassou et al., 2008). The sapropel units are thought to reflect accumulation in anoxic bottom waters during times of enhanced freshwater flow into the Mediterranean from now inactive Saharan rivers and from the Nile (Scrivner et al., 2004; Tzedakis, 2009). The influence of the summer monsoon over northern Africa was apparently stronger, and Nile floods more extreme, during intervals of sapropel accumulation (Freydier et al., 2001; Ducassou et al., 2008; Tzedakis, 2009), and there is some evidence of enhanced winter rainfall over northern Africa at these times (Rossignol-Strick, 1985). Many of these inferences about former Nile floods are based on indirect and often very 
circumstantial evidence, as are the inferences about variations in winter rainfall and in the summer monsoon regime (Claussen et al., 1998). There is therefore a need to test the marine depositional models (and derived climate models) (Chylek et al., 2001) against a well-dated set of terrestrial archives able to provide independent insights into the climatic changes in the northeast quadrant of Africa. The first step is to obtain high-resolution records of late Quaternary hydro-climatic change from fluvial, aeolian and lacustrine sedimentary sequences and landforms in the Nile basin.

Until very recently the reconstruction of late Quaternary prehistoric environments in the Sahara and Nile valley was based primarily upon chronologies obtained through radiocarbon dating of organic and inorganic carbon from archaeological sites characterised by varying degrees of disturbance and preservation (Adamson et al., 1974; Clark, 1980, 1989; Jousse, 2004). Kuper and Kröpelin (2006) analysed the radiocarbon dates obtained from 150 archaeological sites in the eastern Sahara to obtain a detailed history of Holocene climatic fluctuations in this vast region. However, as they note, there are still major gaps in the spatial and temporal distribution of welldated prehistoric sites. Other sources of palaeoclimatic data for this region are river, lake and dune deposits and their associated plant and animal remains (Ritchie et al., 1985; Abell and Hoelzmann, 2000; Gasse, 2000; Hoelzmann et al., 2000, 2004). For example, in the valley of the White Nile, a series of alluvial sediments east of the present river span the last 15000 years (Williams et al., 2006; Williams, 2009) and a less well-dated sequence extends to over $240 \mathrm{kyr}$ (Williams et al., 2003). The White Nile has on occasion acted as a bridge between the desert steppes to the north and the savanna woodlands to the south; on other occasions it has acted as a swamp or water barrier between the lands to the east and west as well as to arrivals from the north, including the two Roman centurions sent by the Emperor Nero to find the sources of the Nile two thousand years ago. However, there are no dates for the vast area immediately west of the White Nile. In addition, many of the dune and river deposits are devoid of carbon and so are not amenable to radiocarbon dating.

\subsection{Aims of this study}

As noted above, our ultimate aim is to reconstruct the late Quaternary environmental history of the Nile from the headwaters to the sea. This paper presents new chronometric data that allow us to reconstruct late Quaternary environmental changes in the White Nile valley and further downstream in the valley of the main Nile (Figs. $1-4)$. To this end, we have embarked upon a systematic programme of optically stimulated luminescence (OSL) dating supplemented where possible by AMS radiocarbon dating, the initial results of which we report here. Our results derive from 23 OSL and 28 AMS ${ }^{14} \mathrm{C}$ dates (Tables 1-4) obtained from river, lake and dune sediments collected from the main Nile valley in northern Sudan in 2005 and from the White Nile valley in central Sudan in 2006, supplemented where appropriate by ages obtained from previous studies in this region. The sediments were particularly well suited to optical dating on account of their abundant content of bright quartz. Measurements were carried out using small aliquots in order to detect any incomplete bleaching of material. We have used the Fairbanks 0107 calibration curve available online at www.radiocarbon.ldeo.columbia.edu/ (Fairbanks et al., 2005) to convert the radiocarbon ages into calibrated ages, here quoted as cal kyr. Rounding of results is to the nearest one hundred years (Tables 3 and 4).

\section{Quaternary geology and geomorphology of the lower White Nile valley}

The lower White Nile valley is bounded to the east by a gently sloping upland of deep clays over weathered Basement Complex rocks, and to the west by a low ridge of Cretaceous sediments ('Nubian Sandstone') backed by the Qoz Abu Dulu sand ridge in the north and by the distal sector of the Khor Abu Habl fan in the south (Plate 1; Fig. 2). The White Nile floodplain-terrace complex consists of a terminal Pleistocene-early Holocene alluvial plain with a southnorth gradient of 1:100 000 bounded by the $382 \mathrm{~m}$ contour, and a late Pleistocene alluvial plain which rises to a sharp break of slope at 386 m elevation (Sir Alexander Gibb and Partners, 1954; Gunn, 1982; Williams et al., 2000, 2006). A well-defined beach ridge of rolled quartz gravels and coarse sand at $386 \mathrm{~m}$ elevation is clearly visible on the ground east of the White Nile as far north as $13^{\circ} 15^{\prime} \mathrm{N}$ (Plate 1; Fig. 2). The Khor Abu Habl fan consists of eastward flowing distributary channels partially disrupted by a series of low linear dunes aligned roughly south-north, parallel to the dominant wind direction during the winter dry season (Plate 1). We collected samples of quartz sand and silt from each of these geomorphic units for OSL dating and for particle size analysis as well as fossil gastropod shells for AMS radiocarbon dating and for palaeoecological and stable isotope analysis.

\section{Quaternary geology and geomorphology of the Nile valley, northern Sudan}

The area sampled in northern Sudan extends up to $80 \mathrm{~km}$ west of and up to130 km northeast of the Nile, which in this sector runs for roughly $150 \mathrm{~km}$ to the southwest, $60 \mathrm{~km}$ to the northwest and then for over $200 \mathrm{~km}$ to the north, between the fourth and third cataracts (Figs. 1 and 3). The orientation of the river reflects structural control by tectonic lineaments that have been reactivated at intervals since the Proterozoic and which also control the present-day orientation of the Red Sea, Gulf of Aden and Ethiopian Rift (Adamson et al., 1993). Areas of moderate to high relief coincide with outcrops of Basement Complex gneisses and granites, Cretaceous sediments ('Nubian Sandstone') and Cenozoic dolerites and basalts. Undulating gravel plains overlying Cretaceous sediments are extensive south of and parallel to the Nile. The abundance of agates within the gravels is consistent with a volcanic source, most probably from local basalts, although a more distal Ethiopian source from the Blue Nile is also possible, as in the area south of Khartoum. The alluvial landforms include Holocene and older floodplains, terraces and palaeochannels (Seleim and Letti Basins), with patches of locally derived alluvium. The lacustrine plains of the Qaab Depression are of particular interest, being connected by a narrow channel to the former Nile (Plate 2). We examined 28 sections in the field (see Fig. 3 for site locations), which allowed us to sample each of the main fluvial, lacustrine and aeolian depositional units and to select the most representative ones for dating and other analyses (Fig. 4).

\section{Optically stimulated luminescence dating procedures}

Eleven samples were collected for optically stimulated luminescence (OSL) dating from river terraces and lake sediments in the main Nile Valley, northern Sudan (sample series N) and thirteen samples from dunes, beach sands and alluvial sands in the White Nile Valley, central Sudan (sample series S). Figs. 2-4 show the locations and stratigraphy of the southern and northern sample sites. The sample numbers and corresponding laboratory designations are shown in Tables 1 and 2.

We collected the samples by inserting an opaque tube into the sediment. This was then sealed at both ends and wrapped in black plastic. In the laboratory the material from both ends of the tube, which would have been exposed to light, was scraped out and used for environmental dose rate measurements. 

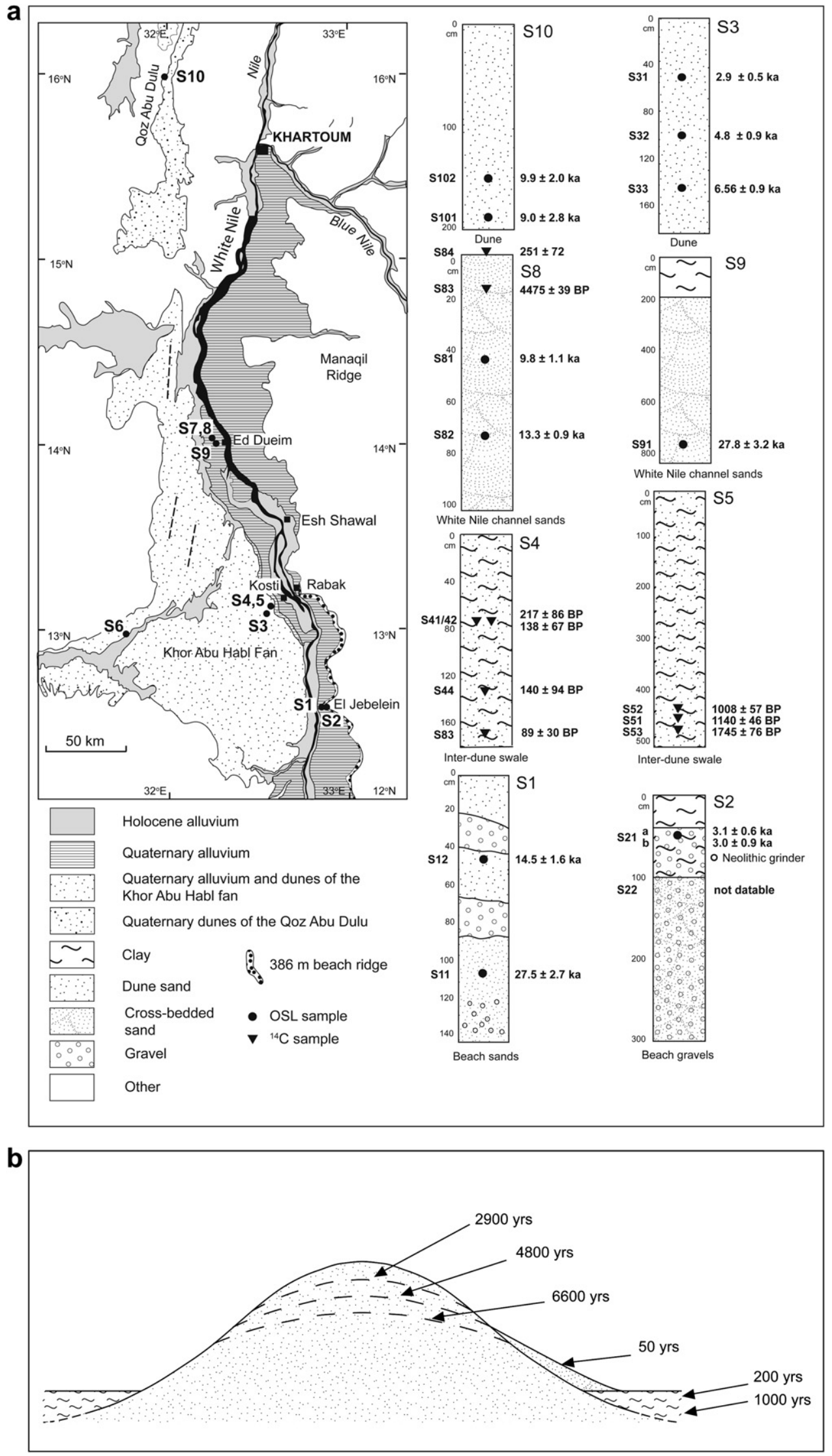

Fig. 2. (a) Geomorphic map with location of dated stratigraphic sections in the White Nile valley, central Sudan. Geological boundaries based on the 1988 Geological Research Authority of the Sudan 1:500,000 map sheets 9 (Khartoum) and 5 (Dongola and Berber). Note the different vertical scales of the sections. (b) Ages of Holocene dune accretion and clay deposition in the swales between dunes, distal Khor Abu Habl fan west of the White Nile, central Sudan. 


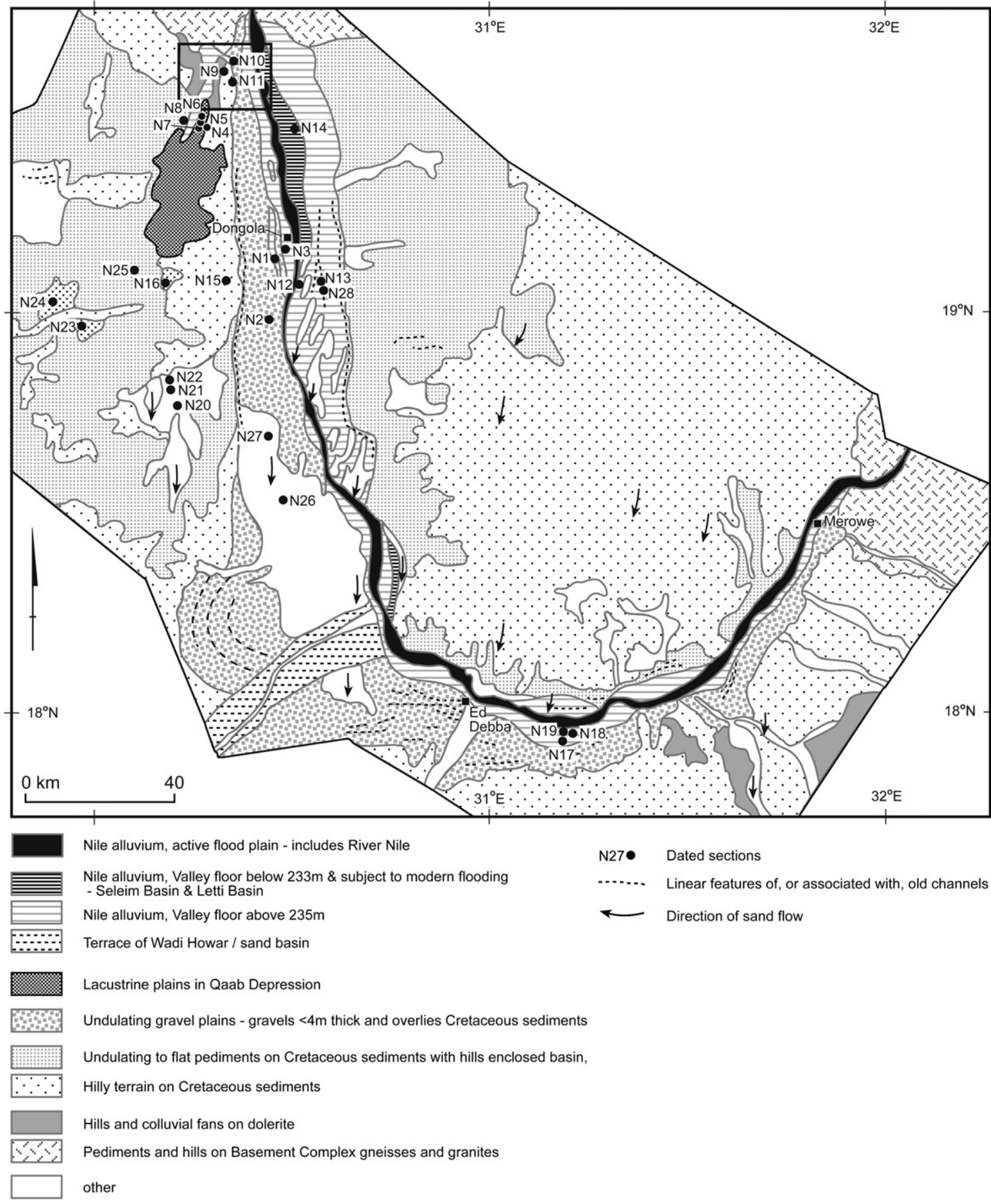

Fig. 3. Geomorphic map with location of dated stratigraphic sections in the main Nile valley, northern Sudan. Geomorphic boundaries based upon field mapping supplemented by satellite imagery. The category other includes local alluvium of the Goleid plains and basins, and aeolian sand dunes. This reach is bounded by the 3rd and 4 th cataracts.

Samples were prepared using standard procedures, summarised as follows. A $20 \%$ solution of hydrochloric acid was used to digest carbonates, followed by treatment with sodium hydroxide solution to break up clay aggregates and remove any small amounts of organic material. Grains in the ranges 125-180 $\mu \mathrm{m}$ and $180-212 \mu \mathrm{m}$ were selected by sieving, then etched for $40 \mathrm{~min}$ in $40 \%$ hydrofluoric acid to remove feldspar and other non-quartz material and to remove the outer $9 \mu \mathrm{m}$ of the quartz grains. This eliminates the effect of alpha particle contribution to the irradiation of the grains. The material was then re-sieved at the same fraction to remove any remaining feldspar grains, washed in hot hydrochloric acid to remove fluorides and floated in $2.67 \mathrm{~g} / \mathrm{cm}^{3}$ sodium polytungstate to remove heavy minerals. Finally, magnetic material was removed by passing through a Charles W. Cook magnetic separator. All the laboratory procedures were carried out in subdued red light. The $125-180 \mu \mathrm{m}$ material was used to carry out luminescence measurements using small aliquots as described below; the 180-212 $\mu \mathrm{m}$ material was retained in the event that single grain measurements might be required.

Uranium and thorium contents were determined by thick source alpha counting (TSAC) and potassium by X-ray spectrometry (XRS). Uranium and thorium contents were also obtained by delayed neutron analysis (DNA) and neutron activation analysis 

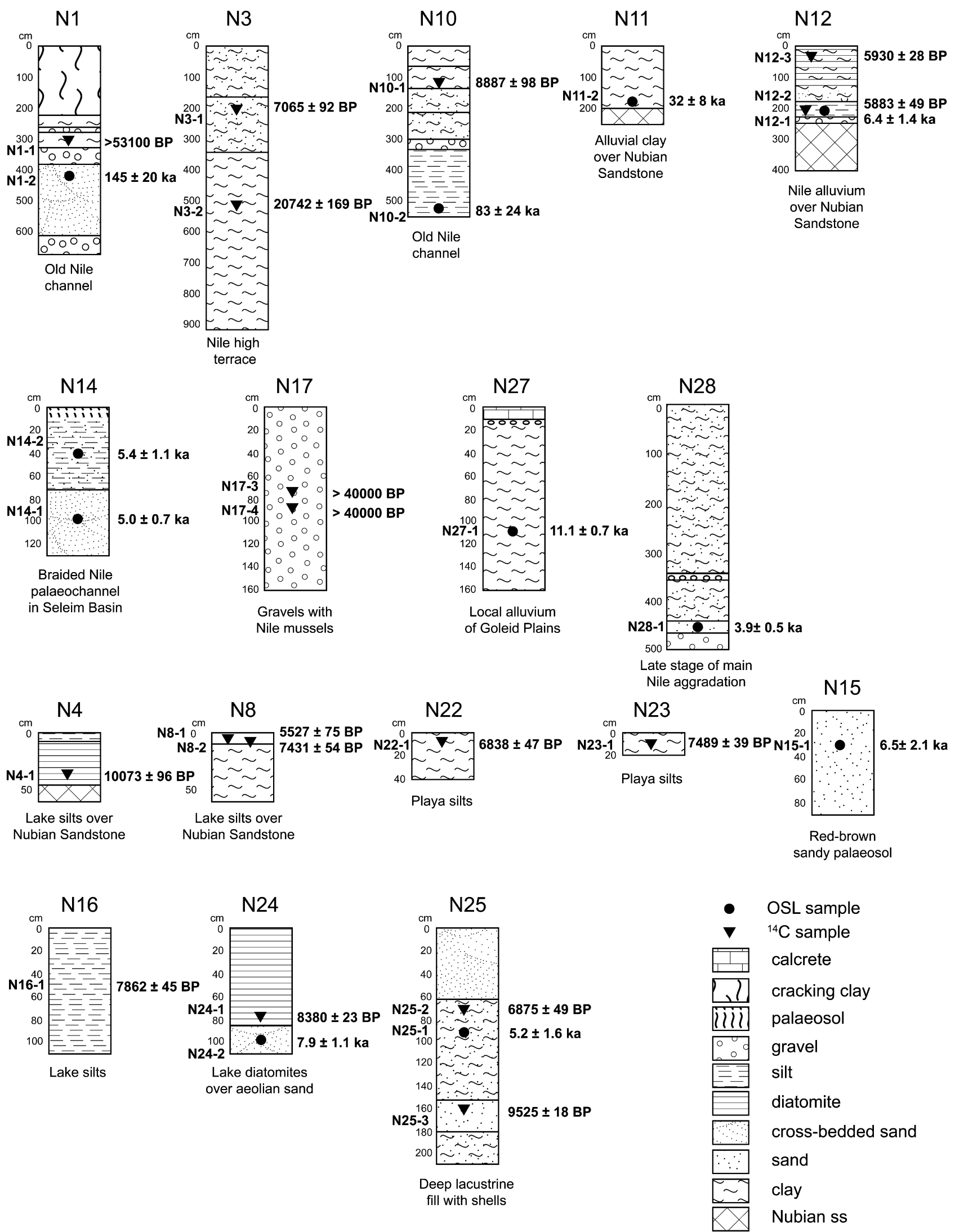

Fig. 4. Dated stratigraphic sections in the main Nile valley, northern Sudan, showing Nile terraces, former Nile channels and tributaries, lake silts, diatomaceous silts, and aeolian sands. 
Table 1

Determination of environmental dose rates. In the column headed "Analysis method" A denotes determination of uranium (U) and thorium (Th) contents using thick source alpha counting; DN denotes determination of U by Delayed Neutron Analysis and Th by Neutron Activation Analysis; Arpt denotes a repetition of the alpha count measurement. The dose rate used for age determination is the weighted average of the measurements.

\begin{tabular}{|c|c|c|c|c|c|c|c|c|c|c|c|c|c|c|}
\hline \multirow[t]{2}{*}{ Sample } & \multirow{2}{*}{$\begin{array}{l}\text { Laboratory } \\
\text { Number }\end{array}$} & \multirow{2}{*}{$\begin{array}{l}\text { Analysis } \\
\overline{\text { Method }}\end{array}$} & \multicolumn{2}{|l|}{$\mathrm{U}$} & \multicolumn{2}{|l|}{ Th } & \multirow{2}{*}{$\frac{\mathrm{K} \%}{+1-5 \%}$} & \multirow{2}{*}{$\begin{array}{l}\mathrm{H}_{2} \mathrm{O} \% \\
+1-10 \%\end{array}$} & \multirow{2}{*}{$\frac{\text { Depth }}{(\mathrm{m})}$} & \multirow{2}{*}{$\begin{array}{l}\text { Cosmic } \\
\text { Gy/kyr } \\
+1-10 \%\end{array}$} & \multicolumn{2}{|c|}{ Dose rate } & \multicolumn{2}{|c|}{$\begin{array}{l}\text { Average dose } \\
\text { rate }\end{array}$} \\
\hline & & & ppm & Error & $\mathrm{ppm}$ & Error & & & & & $\mathrm{Gy} / \mathrm{kyr}$ & Error & Gy/kyr & Error \\
\hline S1-1 & AdGL06001 & $\begin{array}{l}\text { A } \\
\text { DN }\end{array}$ & $\begin{array}{l}1.002 \\
0.810\end{array}$ & $\begin{array}{l}0.263 \\
0.100\end{array}$ & $\begin{array}{l}3.843 \\
3.400\end{array}$ & $\begin{array}{l}0.885 \\
0.300\end{array}$ & 0.149 & 3.250 & 1.100 & 0.180 & $\begin{array}{l}0.807 \\
0.733\end{array}$ & $\begin{array}{l}0.024 \\
0.023\end{array}$ & 0.770 & 0.024 \\
\hline S1-2 & AdGL06002 & $\begin{array}{l}\text { A } \\
\text { DN } \\
\text { A rpt }\end{array}$ & $\begin{array}{l}0.957 \\
0.570 \\
0.197\end{array}$ & $\begin{array}{l}0.298 \\
0.090 \\
0.607\end{array}$ & $\begin{array}{l}5.002 \\
3.100 \\
7.360\end{array}$ & $\begin{array}{l}1.009 \\
0.300 \\
1.009\end{array}$ & 0.565 & 2.480 & 0.500 & 0.190 & $\begin{array}{l}1.293 \\
1.061 \\
1.264\end{array}$ & $\begin{array}{l}0.041 \\
0.039 \\
0.038\end{array}$ & 1.206 & 0.040 \\
\hline S2-1a & AdGL06003 & $\begin{array}{l}\text { A } \\
\text { DN }\end{array}$ & $\begin{array}{l}1.199 \\
0.860\end{array}$ & $\begin{array}{l}0.256 \\
0.100\end{array}$ & $\begin{array}{l}3.851 \\
3.700\end{array}$ & $\begin{array}{l}0.862 \\
0.300\end{array}$ & 0.620 & 4.850 & 0.560 & 0.190 & $\begin{array}{l}1.278 \\
1.192\end{array}$ & $\begin{array}{l}0.038 \\
0.040\end{array}$ & 1.235 & 0.039 \\
\hline $\mathrm{S} 2-1 \mathrm{~b}$ & AdGL06004 & $\begin{array}{l}\text { A } \\
\text { DN }\end{array}$ & $\begin{array}{l}0.923 \\
1.000\end{array}$ & $\begin{array}{l}0.297 \\
0.110\end{array}$ & $\begin{array}{l}5.900 \\
4.300\end{array}$ & $\begin{array}{l}1.002 \\
0.300\end{array}$ & 0.666 & 4.390 & 0.560 & 0.190 & $\begin{array}{l}1.400 \\
1.311\end{array}$ & $\begin{array}{l}0.042 \\
0.048\end{array}$ & 1.356 & 0.045 \\
\hline S2-2 & AdGL06005 & $\begin{array}{l}\text { A } \\
\text { DN }\end{array}$ & $\begin{array}{l}0.778 \\
0.420\end{array}$ & $\begin{array}{l}0.162 \\
0.090\end{array}$ & $\begin{array}{l}2.306 \\
1.600\end{array}$ & $\begin{array}{l}0.543 \\
0.100\end{array}$ & 0.330 & 2.600 & 1.060 & 0.180 & $\begin{array}{l}0.824 \\
0.694\end{array}$ & $\begin{array}{l}0.025 \\
0.024\end{array}$ & 0.759 & 0.025 \\
\hline S3-1 & AdGL06006 & $\begin{array}{l}\text { A } \\
\text { DN }\end{array}$ & $\begin{array}{l}0.609 \\
0.450\end{array}$ & $\begin{array}{l}0.100 \\
0.090\end{array}$ & $\begin{array}{l}1.498 \\
1.300\end{array}$ & $\begin{array}{l}0.334 \\
0.100\end{array}$ & 0.247 & 0.460 & 0.530 & 0.190 & $\begin{array}{l}0.675 \\
0.624\end{array}$ & $\begin{array}{l}0.020 \\
0.046\end{array}$ & 0.650 & 0.030 \\
\hline S3-2 & AdGL06007 & $\begin{array}{l}\text { A } \\
\text { DN }\end{array}$ & $\begin{array}{l}0.748 \\
0.480\end{array}$ & $\begin{array}{l}0.103 \\
0.090\end{array}$ & $\begin{array}{l}1.467 \\
1.900\end{array}$ & $\begin{array}{l}0.342 \\
0.200\end{array}$ & 0.256 & 0.590 & 1.030 & 0.180 & $\begin{array}{l}0.704 \\
0.668\end{array}$ & $\begin{array}{l}0.020 \\
0.048\end{array}$ & 0.699 & 0.030 \\
\hline S3-3 & AdGL06008 & $\begin{array}{l}\text { A } \\
\text { DN } \\
\text { A rpt }\end{array}$ & $\begin{array}{l}0.797 \\
0.450 \\
0.309\end{array}$ & $\begin{array}{l}0.140 \\
0.090 \\
0.147\end{array}$ & $\begin{array}{l}1.483 \\
1.200 \\
2.158\end{array}$ & $\begin{array}{l}0.465 \\
0.100 \\
0.497\end{array}$ & 0.253 & 0.930 & 1.660 & 0.170 & $\begin{array}{l}0.701 \\
0.600 \\
0.633\end{array}$ & $\begin{array}{l}0.032 \\
0.029 \\
0.019\end{array}$ & 0.650 & 0.026 \\
\hline S8-1 & AdGL06009 & $\begin{array}{l}\text { A } \\
\text { DN }\end{array}$ & $\begin{array}{l}0.628 \\
0.760\end{array}$ & $\begin{array}{l}0.218 \\
0.100\end{array}$ & $\begin{array}{l}3.455 \\
2.500\end{array}$ & $\begin{array}{l}0.738 \\
0.200\end{array}$ & 0.495 & 0.000 & 0.380 & 0.190 & $\begin{array}{l}1.058 \\
1.023\end{array}$ & $\begin{array}{l}0.032 \\
0.037\end{array}$ & 1.041 & 0.034 \\
\hline S8-2 & AdGL06010 & $\begin{array}{l}\text { A } \\
\text { DN }\end{array}$ & $\begin{array}{l}0.537 \\
0.420\end{array}$ & $\begin{array}{l}0.111 \\
0.090\end{array}$ & $\begin{array}{l}1.172 \\
1.200\end{array}$ & $\begin{array}{l}0.373 \\
0.100\end{array}$ & 0.341 & 0.000 & 0.920 & 0.180 & $\begin{array}{l}0.718 \\
0.692\end{array}$ & $\begin{array}{l}0.022 \\
0.031\end{array}$ & 0.709 & 0.025 \\
\hline S9-1 & AdGL06011 & $\begin{array}{l}\text { A } \\
\text { DN }\end{array}$ & $\begin{array}{l}0.301 \\
0.370\end{array}$ & $\begin{array}{l}0.055 \\
0.090\end{array}$ & $\begin{array}{l}0.694 \\
0.730\end{array}$ & $\begin{array}{l}0.184 \\
0.080\end{array}$ & 0.251 & 1.260 & 8.000 & 0.100 & $\begin{array}{l}0.457 \\
0.482\end{array}$ & $\begin{array}{l}0.014 \\
0.020\end{array}$ & 0.465 & 0.016 \\
\hline S10-1 & AdGL06012 & $\begin{array}{l}\text { A } \\
\text { DN }\end{array}$ & $\begin{array}{l}0.491 \\
0.350\end{array}$ & $\begin{array}{l}0.084 \\
0.090\end{array}$ & $\begin{array}{l}1.103 \\
0.960\end{array}$ & $\begin{array}{l}0.300 \\
0.100\end{array}$ & 0.216 & 0.150 & 1.790 & 0.170 & $\begin{array}{l}0.571 \\
0.528\end{array}$ & $\begin{array}{l}0.017 \\
0.029\end{array}$ & 0.558 & 0.021 \\
\hline S10-2 & AdGL06013 & $\begin{array}{l}\text { A } \\
\text { DN }\end{array}$ & $\begin{array}{l}0.424 \\
0.490\end{array}$ & $\begin{array}{l}0.089 \\
0.090\end{array}$ & $\begin{array}{l}1.273 \\
1.100\end{array}$ & $\begin{array}{l}0.303 \\
0.100\end{array}$ & 0.198 & 1.000 & 1.420 & 0.170 & $\begin{array}{l}0.546 \\
0.550\end{array}$ & $\begin{array}{l}0.016 \\
0.029\end{array}$ & 0.548 & 0.021 \\
\hline N1-2 & AdGl06016 & $\begin{array}{l}\text { A } \\
\text { DN }\end{array}$ & $\begin{array}{l}0.761 \\
0.660\end{array}$ & $\begin{array}{l}0.131 \\
0.090\end{array}$ & $\begin{array}{l}1.766 \\
1.800\end{array}$ & $\begin{array}{l}0.417 \\
0.200\end{array}$ & 0.343 & 1.010 & 4.150 & 0.141 & $\begin{array}{l}0.768 \\
0.746\end{array}$ & $\begin{array}{l}0.023 \\
0.031\end{array}$ & 0.757 & 0.027 \\
\hline N10-2 & AdGl06017 & $\begin{array}{l}\mathrm{A} \\
\mathrm{DN}\end{array}$ & $\begin{array}{l}0.831 \\
0.680\end{array}$ & $\begin{array}{l}0.190 \\
0.090\end{array}$ & $\begin{array}{l}3.370 \\
2.100\end{array}$ & $\begin{array}{l}0.637 \\
0.200\end{array}$ & 0.425 & 4.560 & 5.300 & 0.127 & $\begin{array}{l}0.986 \\
0.807\end{array}$ & $\begin{array}{l}0.030 \\
0.030\end{array}$ & 0.897 & 0.030 \\
\hline N11-2 & AdGl06018 & $\begin{array}{l}\text { A } \\
\text { DN }\end{array}$ & $\begin{array}{l}3.950 \\
3.990\end{array}$ & $\begin{array}{l}0.438 \\
0.180\end{array}$ & $\begin{array}{l}6.254 \\
7.800\end{array}$ & $\begin{array}{l}0.915 \\
0.400\end{array}$ & 0.177 & 4.760 & 2.000 & 0.174 & $\begin{array}{l}1.637 \\
1.775\end{array}$ & $\begin{array}{l}0.049 \\
0.064\end{array}$ & 1.706 & 0.056 \\
\hline N12-1 & AdGl06019 & $\begin{array}{l}\text { A } \\
\text { DN }\end{array}$ & $\begin{array}{l}1.571 \\
1.640\end{array}$ & $\begin{array}{l}0.275 \\
0.120\end{array}$ & $\begin{array}{l}6.327 \\
6.000\end{array}$ & $\begin{array}{l}0.913 \\
0.400\end{array}$ & 0.991 & 8.110 & 2.270 & 0.165 & $\begin{array}{l}1.776 \\
1.771\end{array}$ & $\begin{array}{l}0.053 \\
0.051\end{array}$ & 1.774 & 0.052 \\
\hline N14-1 & AdGl06020 & $\begin{array}{l}\text { A } \\
\text { DN }\end{array}$ & $\begin{array}{l}0.797 \\
0.520\end{array}$ & $\begin{array}{l}0.134 \\
0.080\end{array}$ & $\begin{array}{l}1.537 \\
1.400\end{array}$ & $\begin{array}{l}0.443 \\
0.200\end{array}$ & 0.842 & 0.230 & 0.800 & 0.191 & $\begin{array}{l}1.310 \\
1.234\end{array}$ & $\begin{array}{l}0.039 \\
0.040\end{array}$ & 1.272 & 0.040 \\
\hline N14-2 & AdGl06021 & $\begin{array}{l}\text { A } \\
\text { DN }\end{array}$ & $\begin{array}{l}0.958 \\
0.790\end{array}$ & $\begin{array}{l}0.189 \\
0.090\end{array}$ & $\begin{array}{l}2.388 \\
2.600\end{array}$ & $\begin{array}{l}0.468 \\
0.300\end{array}$ & 1.283 & 1.720 & 0.450 & 0.198 & $\begin{array}{l}1.773 \\
1.776\end{array}$ & $\begin{array}{l}0.053 \\
0.059\end{array}$ & 1.775 & 0.056 \\
\hline N15-1 & AdGl06022 & $\begin{array}{l}\text { A } \\
\text { DN }\end{array}$ & $\begin{array}{l}2.062 \\
1.630\end{array}$ & $\begin{array}{l}0.416 \\
0.130\end{array}$ & $\begin{array}{l}4.449 \\
5.800\end{array}$ & $\begin{array}{l}0.893 \\
0.300\end{array}$ & 0.285 & 2.400 & 0.400 & 0.199 & $\begin{array}{l}1.250 \\
1.268\end{array}$ & $\begin{array}{l}0.046 \\
0.048\end{array}$ & 1.259 & 0.047 \\
\hline $\mathrm{N} 24-2$ & AdGl06023 & $\begin{array}{l}\text { A } \\
\text { DN }\end{array}$ & $\begin{array}{l}1.435 \\
1.420\end{array}$ & $\begin{array}{l}0.452 \\
0.110\end{array}$ & $\begin{array}{l}7.616 \\
6.200\end{array}$ & $\begin{array}{l}1.523 \\
0.200\end{array}$ & 0.386 & 0.340 & 1.000 & 0.187 & $\begin{array}{l}1.428 \\
1.341\end{array}$ & $\begin{array}{l}0.043 \\
0.040\end{array}$ & 1.385 & 0.042 \\
\hline N25-1 & AdGl06024 & $\begin{array}{l}\text { A } \\
\text { DN }\end{array}$ & $\begin{array}{l}1.979 \\
2.540\end{array}$ & $\begin{array}{l}0.324 \\
0.160\end{array}$ & $\begin{array}{l}4.961 \\
6.000\end{array}$ & $\begin{array}{l}1.079 \\
0.400\end{array}$ & 0.427 & 2.000 & 0.950 & 0.188 & $\begin{array}{l}1.136 \\
1.609\end{array}$ & $\begin{array}{l}0.034 \\
0.057\end{array}$ & 1.373 & 0.046 \\
\hline N27-1 & AdGl06025 & $\begin{array}{l}\text { A } \\
\text { DN }\end{array}$ & $\begin{array}{l}2.863 \\
1.900\end{array}$ & $\begin{array}{l}0.261 \\
0.100\end{array}$ & $\begin{array}{l}4.185 \\
6.200\end{array}$ & $\begin{array}{l}0.854 \\
0.500\end{array}$ & 0.676 & 0.940 & 1.100 & 0.187 & $\begin{array}{l}1.789 \\
1.725\end{array}$ & $\begin{array}{l}0.054 \\
0.053\end{array}$ & 1.757 & 0.054 \\
\hline N28-1 & AdGl06026 & $\begin{array}{l}\text { A } \\
\text { DN }\end{array}$ & $\begin{array}{l}1.710 \\
1.500\end{array}$ & $\begin{array}{l}0.298 \\
0.100\end{array}$ & $\begin{array}{l}4.542 \\
4.600\end{array}$ & $\begin{array}{l}1.710 \\
0.500\end{array}$ & 0.978 & 1.960 & 4.800 & 0.129 & $\begin{array}{l}1.754 \\
1.714\end{array}$ & $\begin{array}{l}0.053 \\
0.053\end{array}$ & 1.734 & 0.053 \\
\hline
\end{tabular}

(NAA) in order to provide a check on the TSAC measurements and to enable any radioactive disequilibrium to be detected. The cosmic ray contribution was obtained using the relationship between cosmic ray penetration, depth and latitude determined by Prescott and Hutton (1994). Water content was measured on receipt of the samples by weighing, drying overnight at $180^{\circ} \mathrm{C}$, and re-weighing. (Note: an increase of $1 \%$ in the water content causes an increase of approximately $1 \%$ in the measured age of the sample). The results of 
Table 2

Dose rates, equivalent doses and OSL ages for $\mathrm{N}$ and $\mathrm{S}$ sample sets.

\begin{tabular}{|c|c|c|c|c|c|c|c|}
\hline \multirow[t]{2}{*}{ Sample } & \multirow{2}{*}{$\frac{\text { Laboratory }}{\text { Number }}$} & \multicolumn{2}{|l|}{ Dose rate } & \multicolumn{2}{|l|}{ ED } & \multicolumn{2}{|l|}{ Age } \\
\hline & & (Gy/kyr) & Error & $(\mathrm{Gy})$ & Error & (kyr) & $\overline{\text { Error }}$ \\
\hline S1-1 & AdGL06001 & 0.77 & 0.02 & 21.2 & 2.1 & 27.5 & 2.7 \\
\hline S1-2 & AdGL06002 & 1.21 & 0.04 & 17.4 & 3.2 & 14.5 & 1.6 \\
\hline S2-1a & AdGL06003 & 1.24 & 0.04 & 3.9 & 0.8 & 3.1 & 0.6 \\
\hline S2-1b & AdGL06004 & 1.36 & 0.05 & 4.1 & 1.2 & 3.0 & 0.9 \\
\hline $\mathrm{S} 2-2$ & AdGL06005 & 0.76 & 0.03 & \multicolumn{2}{|c|}{$\begin{array}{l}\text { Not } \\
\text { determined }\end{array}$} & \multicolumn{2}{|c|}{ undatable } \\
\hline S3-1 & AdGL06006 & 0.65 & 0.03 & 1.9 & 0.3 & 2.9 & 0.5 \\
\hline S3-2 & AdGL06007 & 0.70 & 0.03 & 3.4 & 0.6 & 4.8 & 0.9 \\
\hline S3-3 & AdGL06008 & 0.65 & 0.03 & 4.3 & 0.6 & 6.6 & 0.9 \\
\hline S8-1 & AdGL06009 & 1.04 & 0.03 & 10.3 & 1.1 & 9.8 & 1.1 \\
\hline S8-2 & AdGL06010 & 0.71 & 0.03 & 9.4 & 0.6 & 13.3 & 0.9 \\
\hline S9-1 & AdGL06011 & 0.47 & 0.02 & 12.9 & 1.5 & 27.8 & 3.2 \\
\hline S10-1 & AdGL06012 & 0.56 & 0.02 & 5.0 & 1.5 & 9.0 & 2.8 \\
\hline S10-2 & AdGL06013 & 0.55 & 0.03 & 5.4 & 1.1 & 9.9 & 2.0 \\
\hline N1-2 & AdGL06016 & 0.76 & 0.027 & 110 & 15 & 145 & 20 \\
\hline N10-2 & AdGL06017 & 0.90 & 0.03 & 74.2 & 21.7 & 83 & 24 \\
\hline N11-2 & AdGL06018 & 1.71 & 0.056 & 55.1 & 13.3 & 32 & 8 \\
\hline N12-1 & AdGL06019 & 1.77 & 0.05 & 11.4 & 2.6 & 6.4 & 1.4 \\
\hline N14-1 & AdGL06020 & 1.27 & 0.04 & 6.4 & 0.9 & 5.0 & 0.7 \\
\hline N14-2 & AdGL06021 & 1.78 & 0.056 & 9.5 & 1.9 & 5.4 & 1.1 \\
\hline N15-1 & AdGL06022 & 1.26 & 0.05 & 8.2 & 2.6 & 6.5 & 2.1 \\
\hline $\mathrm{N} 24-2$ & AdGL06023 & 1.39 & 0.04 & 10.9 & 1.5 & 7.9 & 1.1 \\
\hline N25-1 & AdGL06024 & 1.37 & 0.05 & 7.2 & 2.2 & 5.2 & 1.6 \\
\hline N27-1 & AdGL06025 & 1.76 & 0.05 & 19.5 & 1.3 & 11.1 & 0.7 \\
\hline N28-1 & AdGL06026 & 1.73 & 0.05 & 6.8 & 0.9 & 3.9 & 0.5 \\
\hline
\end{tabular}

these measurements, and the calculated dose rates, are given in Table 1.

Luminescence measurements were carried out using small aliquots. Each of these consisted of between about 50 and 100 grains in the $125-180 \mu \mathrm{m}$ range, transferred to the centre of a silicone oil coated $10 \mathrm{~mm}$ diameter steel disc using a rounded pinhead. Pilot studies had indicated that this number of grains would enable individual differences between the aliquots (due to differential bleaching of the grains) to be detected, while still providing measurable luminescence. Measurements were carried out using a Risø TL/OSL reader model TL-DA 10. Radiation was applied using a ${ }^{90} \mathrm{Sr} \beta$ source (strength $0.0145 \mathrm{~Gy} / \mathrm{s}$ ), stimulation was by green light of wavelength $500-550 \mathrm{~nm}$, and a 9635Q photomultiplier fitted with a U340 filter was used for detection. The measurement procedure followed the single aliquot regeneration (SAR) protocol described by Murray and Wintle (2000). Measurements were made at four regeneration points, plus a zero dose regeneration point to test for recuperation and a repeat of the first dose to test for recycling. Between 14 and 29 aliquots were run for each sample and an equivalent dose (ED) determined for each aliquot which had a recycling ratio within $15 \%$ of unity and negligible recuperation. Equivalent dose is the laboratory-applied dose that produces luminescence equal to that of the natural sample and is hence equal to the total burial dose.

For each sample, the measured EDs of the small aliquots were plotted in the form of a weighted histogram (also know as a probability density plot). These are shown in Figs. 5 and 6. Samples N141, N142, N151, N281 and S81 showed an approximately symmetrical (Gaussian) spread of EDs, and the value to be used in the age calculation was taken as the weighted mean of all the measurements. All the other samples showed varying degrees of scatter and irregularity in their ED distributions. For these, the method described by Prescott et al. (2007) was used to determine the value representative of deposition of the sediment and hence to be used in the age determination. Essentially, this method assumes

Table 3

AMS radiocarbon and optically stimulated luminescence ages for sites in the White Nile valley, central Sudan.

\begin{tabular}{|c|c|c|c|c|c|c|}
\hline Sample no. & Laboratory number & Location & $\begin{array}{l}{ }^{14} \mathrm{C} \text { age } \\
\text { (years BP) }\end{array}$ & $\begin{array}{l}{ }^{14} \mathrm{C} \text { age } \\
\text { (calibrated BP) }\end{array}$ & & OSL age (kyr) \\
\hline \multicolumn{7}{|c|}{ White Nile right bank, beach ridge east of Jebelein } \\
\hline S1-1 & AdGL06001 & $12^{\circ} 35^{\prime} \mathrm{N} 32^{\circ} 50^{\prime} \mathrm{E}$ & & & & $27.5 \pm 2.7$ \\
\hline S1-2 & AdGL06002 & $12^{\circ} 35^{\prime} \mathrm{N} 32^{\circ} 50^{\prime} \mathrm{E}$ & & & & $14.5 \pm 1.6$ \\
\hline S2-1a & AdGL06003 & $12^{\circ} 30^{\prime} \mathrm{N} 32^{\circ} 50^{\prime} \mathrm{E}$ & & & & $3.1 \pm 0.6$ \\
\hline S2-1b & AdGL06004 & $12^{\circ} 30^{\prime} \mathrm{N} 32^{\circ} 50^{\prime} \mathrm{E}$ & & & & $3.0 \pm 0.9$ \\
\hline \multicolumn{7}{|c|}{ Khor Abu Habl Fan, dune crest } \\
\hline S3-1 & AdGL06006 & $13^{\circ} 05^{\prime} \mathrm{N} 32^{\circ} 30^{\prime} \mathrm{E}$ & & & & $2.9 \pm 0.5$ \\
\hline S3-2 & AdGL06007 & $13^{\circ} 05^{\prime} \mathrm{N} 32^{\circ} 30^{\prime} \mathrm{E}$ & & & & $4.8 \pm 0.9$ \\
\hline S3-3 & AdGL06008 & $13^{\circ} 05^{\prime} \mathrm{N} 32^{\circ} 30^{\prime} \mathrm{E}$ & & & & $6.6 \pm 0.9$ \\
\hline \multicolumn{7}{|c|}{ Khor Abu Habl Fan, well between dunes } \\
\hline S4-1 & Wk-18714 & $13^{\circ} 08^{\prime} \mathrm{N} 32^{\circ} 31^{\prime} \mathrm{E}$ & $202 \pm 33$ & $217 \pm 86$ & $\mathrm{~S}$ & \\
\hline S4-2 & Wk-18715 & $13^{\circ} 08^{\prime} \mathrm{N} 32^{\circ} 31^{\prime} \mathrm{E}$ & $117.3 \pm 0.3 \% \mathrm{M}$ & $138 \pm 67$ & $\mathrm{~S}$ & \\
\hline S4-3 & Wk-18716 & $13^{\circ} 08^{\prime} \mathrm{N} 32^{\circ} 31^{\prime} \mathrm{E}$ & $89 \pm 30$ & & $\mathrm{~S}$ & \\
\hline S4-4 & Wk-18717 & $13^{\circ} 08^{\prime} \mathrm{N} 32^{\circ} 31^{\prime} \mathrm{E}$ & $146 \pm 41$ & $140 \pm 94$ & $\mathrm{C}$ & \\
\hline \multicolumn{7}{|c|}{ Khor Abu Habl Fan, Pila shell from 4.75 m deep well } \\
\hline S5-1 & Wk-18718 & $13^{\circ} 08^{\prime} \mathrm{N} 32^{\circ} 31^{\prime} \mathrm{E}$ & $1215 \pm 28$ & $1140 \pm 46$ & $\mathrm{~S}$ & \\
\hline S5-2 & Wk-18719 & $13^{\circ} 08^{\prime} \mathrm{N} 32^{\circ} 31^{\prime} \mathrm{E}$ & $1108 \pm 53$ & $1008 \pm 57$ & $\mathrm{~S}$ & \\
\hline S5-3 & Wk-18720 & $13^{\circ} 08^{\prime} \mathrm{N} 32^{\circ} 31^{\prime} \mathrm{E}$ & $1816 \pm 60$ & $1745 \pm 76$ & $\mathrm{~S}$ & \\
\hline \multicolumn{7}{|c|}{ Point-bar scrolls west of White Nile north of Ed Dueim } \\
\hline S7-1 & Wk-18721 & $14^{\circ} 04^{\prime} \mathrm{N} 32^{\circ} 14^{\prime} \mathrm{E}$ & $355 \pm 28$ & $418 \pm 57$ & $\mathrm{~S}$ & \\
\hline \multicolumn{7}{|c|}{ Cross-bedded channel sands west of White Nile north of Ed Dueim } \\
\hline S8-1 & AdGL06009 & $14^{\circ} 02^{\prime} \mathrm{N} 32^{\circ} 14^{\prime} \mathrm{E}$ & & & & $9.8 \pm 1.1$ \\
\hline S8-2 & AdGL06010 & $14^{\circ} 02^{\prime} \mathrm{N} 32^{\circ} 14^{\prime} \mathrm{E}$ & & & & $13.3 \pm 0.9$ \\
\hline S8-3 & Wk-18722 & $14^{\circ} 02^{\prime} \mathrm{N} 32^{\circ} 14^{\prime} \mathrm{E}$ & $4017 \pm 30$ & $4475 \pm 39$ & $\mathrm{~S}$ & \\
\hline S8-4 & Wk-18723 & $14^{\circ} 02^{\prime} \mathrm{N} 32^{\circ} 14^{\prime} \mathrm{E}$ & $222 \pm 30$ & $251 \pm 72$ & $\mathrm{~S}$ & \\
\hline \multicolumn{7}{|c|}{ Sand quarry west of White Nile near Ed Dueim } \\
\hline S9-1 & AdGL06011 & $14^{\circ} 00^{\prime} \mathrm{N} 32^{\circ} 16^{\prime} \mathrm{E}$ & & & & $27.8 \pm 3.2$ \\
\hline \multicolumn{7}{|c|}{ Qoz Abu Dulu west of Nile } \\
\hline S10-1 & AdGL06012 & $15^{\circ} 59^{\prime} \mathrm{N} 31^{\circ} 59^{\prime} \mathrm{E}$ & & & & $9.0 \pm 2.8$ \\
\hline S10-2 & AdGL06013 & $15^{\circ} 59^{\prime} \mathrm{N} 31^{\circ} 59^{\prime} \mathrm{E}$ & & & & $9.9 \pm 2.0$ \\
\hline
\end{tabular}


Table 4

AMS radiocarbon and optically stimulated luminescence ages for sites in the main Nile valley, northern Sudan.

\begin{tabular}{|c|c|c|c|c|c|c|}
\hline Sample no. & Laboratory number & Location & ${ }^{14} \mathrm{C}$ age (years BP) & $\begin{array}{l}{ }^{14} \mathrm{C} \text { age } \\
\text { (calibrated } \mathrm{BP} \text { ) }\end{array}$ & & OSL age (kyr) \\
\hline \multicolumn{7}{|c|}{ Deep alluvium in old Nile channel south of Dongola } \\
\hline N1-1 & OZ1985 & $19^{\circ} 07^{\prime} \mathrm{N} 30^{\circ} 26^{\prime} \mathrm{E}$ & $>53100$ & & $\mathrm{~S}$ & \\
\hline N1-2 & AdGL06016 & $19^{\circ} 07^{\prime} \mathrm{N} 30^{\circ} 26^{\prime} \mathrm{E}$ & & & & $145 \pm 20$ \\
\hline N3-1 & OZ1986 & $19^{\circ} 08^{\prime} \mathrm{N} 30^{\circ} 27^{\prime} \mathrm{E}$ & $6170 \pm 60$ & $7065 \pm 92$ & $\mathrm{~S}$ & \\
\hline N3-2 & OZ1988 & $19^{\circ} 08^{\prime} \mathrm{N} 30^{\circ} 27^{\prime} \mathrm{E}$ & $17540 \pm 120$ & $20742 \pm 169$ & $\mathrm{~S}$ & \\
\hline \multicolumn{7}{|c|}{ Lake sediments in Laqiya oasis } \\
\hline N4-1 & Wk-17773 & $19^{\circ} 27^{\prime} \mathrm{N} 30^{\circ} 15^{\prime} \mathrm{E}$ & $8908 \pm 37$ & $10073 \pm 96$ & $\mathrm{~S}$ & \\
\hline N8-1 & Wk-17772 & $19^{\circ} 27^{\prime} \mathrm{N} 30^{\circ} 12^{\prime} \mathrm{E}$ & $6521 \pm 69$ & $7431 \pm 54$ & $\mathrm{~S}$ & \\
\hline N8-2 & OZ1989 & $19^{\circ} 27^{\prime} \mathrm{N} 30^{\circ} 12^{\prime} \mathrm{E}$ & $4780 \pm 60$ & $5527 \pm 75$ & B & \\
\hline \multicolumn{7}{|c|}{ Jebel Hafir Bab al Qaab, centre of old Nile channel } \\
\hline N10-1 & Wk-17774 & $19^{\circ} 37^{\prime} \mathrm{N} 30^{\circ} 20^{\prime} \mathrm{E}$ & $7986 \pm 37$ & $8887 \pm 98$ & $\mathrm{~S}$ & \\
\hline $\mathrm{N} 10-2$ & AdGL06017 & $19^{\circ} 37^{\prime} \mathrm{N} 30^{\circ} 20^{\prime} \mathrm{E}$ & & & & $83 \pm 24$ \\
\hline \multicolumn{7}{|c|}{ Alluvial clay over Nubian Sandstone } \\
\hline N11-2 & AdGL06018 & $19^{\circ} 34^{\prime} \mathrm{N} 30^{\circ} 20^{\prime} \mathrm{E}$ & & & & $32 \pm 8$ \\
\hline \multicolumn{7}{|c|}{ Nile alluvium south of Seleim basin } \\
\hline N12-1 & AdGL06019 & $19^{\circ} 03^{\prime} \mathrm{N} 30^{\circ} 29^{\prime} \mathrm{E}$ & & & & $6.4 \pm 1.4$ \\
\hline $\mathrm{N} 12-2$ & Wk-18995 & $19^{\circ} 03^{\prime} \mathrm{N} 30^{\circ} 29^{\prime} \mathrm{E}$ & $5124 \pm 41$ & $5883 \pm 49$ & $\mathrm{C}$ & \\
\hline $\mathrm{N} 12-3$ & Wk-18996 & $19^{\circ} 03^{\prime} \mathrm{N} 30^{\circ} 29^{\prime} \mathrm{E}$ & $5185 \pm 35$ & $5930 \pm 28$ & $\mathrm{~S}$ & \\
\hline \multicolumn{7}{|c|}{ Right bank of Nile, Wadi Khowi plains } \\
\hline N13-1 & $0 Z 1987$ & $19^{\circ} 04^{\prime} \mathrm{N} 30^{\circ} 33^{\prime} \mathrm{E}$ & $4210 \pm 70$ & $4776 \pm 96$ & B & \\
\hline \multicolumn{7}{|c|}{ Right bank of Nile northeast of Seleim basin } \\
\hline N14-1 & AdGL06020 & $19^{\circ} 27^{\prime} \mathrm{N} 30^{\circ} 30^{\prime} \mathrm{E}$ & & & & $5.0 \pm 0.7$ \\
\hline N14-2 & AdGL06021 & $19^{\circ} 27^{\prime} \mathrm{N} 30^{\circ} 30^{\prime} \mathrm{E}$ & & & & $5.4 \pm 1.1$ \\
\hline \multicolumn{7}{|c|}{ Hilly terrain west of Dongola } \\
\hline N15-1 & AdGL06022 & $19^{\circ} 04^{\prime} \mathrm{N} 30^{\circ} 19^{\prime} \mathrm{E}$ & & & & $6.5 \pm 2.1$ \\
\hline \multicolumn{7}{|c|}{ Lake sediments, Umm Hillal oasis } \\
\hline N16-1 & Wk-18997 & $19^{\circ} 04^{\prime} \mathrm{N} 30^{\circ} 09^{\prime} \mathrm{E}$ & $7025 \pm 37$ & $7862 \pm 45$ & $\mathrm{~S}$ & \\
\hline \multicolumn{7}{|c|}{ Multaga gravel quarry with Nile mussel shells } \\
\hline $\mathrm{N} 17-3$ & Wk-17775 & $17^{\circ} 56^{\prime} \mathrm{N} 31^{\circ} 11^{\prime} \mathrm{E}$ & $>40000$ & & $\mathrm{~S}$ & \\
\hline $\mathrm{N} 17-4$ & Wk-17776 & $17^{\circ} 56^{\prime} \mathrm{N} 31^{\circ} 11^{\prime} \mathrm{E}$ & $>40000$ & & $\mathrm{~S}$ & \\
\hline \multicolumn{7}{|c|}{ Lake sediments, El Bab oasis } \\
\hline N22-1 & Wk-17777 & $18^{\circ} 50^{\prime} \mathrm{N} 30^{\circ} 09^{\prime} \mathrm{E}$ & $6004 \pm 31$ & $6838 \pm 47$ & $\mathrm{~S}$ & \\
\hline \multicolumn{7}{|c|}{ Lake sediments, oasis west of Umm Hillal } \\
\hline N23-1 & Wk-18998 & $18^{\circ} 57^{\prime} \mathrm{N} 29^{\circ} 56^{\prime} \mathrm{E}$ & $6601 \pm 42$ & $7489 \pm 39$ & $\mathrm{~S}$ & \\
\hline N24-1 & Wk-19001 & $19^{\circ} 01^{\prime} \mathrm{N} 29^{\circ} 52^{\prime} \mathrm{E}$ & $7566 \pm 39$ & $8380 \pm 23$ & $\mathrm{~S}$ & \\
\hline N24-2 & AdGL06023 & $19^{\circ} 01^{\prime} \mathrm{N} 29^{\circ} 52^{\prime} \mathrm{E}$ & & & & $7.9 \pm 1.1$ \\
\hline \multicolumn{7}{|c|}{ Lake sediments, Umm Hillal oasis } \\
\hline N25-1 & AdGL06024 & $19^{\circ} 05^{\prime} \mathrm{N} 30^{\circ} 04^{\prime} \mathrm{E}$ & & & & $5.2 \pm 1.6$ \\
\hline $\mathrm{N} 25-2$ & Wk-18999 & $19^{\circ} 05^{\prime} \mathrm{N} 30^{\circ} 04^{\prime} \mathrm{E}$ & $6031 \pm 35$ & $6875 \pm 49$ & $\mathrm{C}$ & \\
\hline N25-3 & Wk-19000 & $19^{\circ} 05^{\prime} \mathrm{N} 30^{\circ} 04^{\prime} \mathrm{E}$ & $8546 \pm 41$ & $9525 \pm 18$ & $\mathrm{C}$ & \\
\hline \multicolumn{7}{|l|}{ Goleid plains } \\
\hline $\mathrm{N} 27-1$ & AdGL06025 & $18^{\circ} 41^{\prime} \mathrm{N} 30^{\circ} 26^{\prime} \mathrm{E}$ & & & & $11.0 \pm 0.7$ \\
\hline \multicolumn{7}{|c|}{ Right bank of Nile, Wadi Khowi } \\
\hline N28-1 & AdGL06026 & $19^{\circ} 04^{\prime} \mathrm{N} 30^{\circ} 34^{\prime} \mathrm{E}$ & & & & $3.9 \pm 0.5$ \\
\hline
\end{tabular}

that a scattered distribution of EDs is most likely due to incomplete bleaching of higher ED grains, and that the ED distribution of fully bleached grains will be approximately Gaussian. Hence, larger ED values were progressively removed from the distribution until an approximately Gaussian distribution was obtained. The procedure is illustrated in Fig. 7.

Sample S22 was problematic. The pilot study showed that the natural dose was close to or above saturation when regenerative doses up to $35 \mathrm{~Gy}$ were applied. This sample was sent to Aberystwyth University for single grain analysis. This showed that the EDs of 230 measurable grains (out of a total of 1000 run) had such a broad scatter, ranging from about $1.5 \mathrm{~Gy}$ to $120 \mathrm{~Gy}$ with no discernable peak value, that any attempt at analysis would be meaningless.

The ED values determined for each sample, the environmental dose rates and ages are given in Tables 1 and 2.

\section{OSL and AMS ${ }^{14} \mathrm{C}$ ages from the southern sites}

\subsection{The Khor Abu Habl distributary channels}

The Khor Abu Habl fan (Plate 1) is a mega-fan, as defined by Leier et al. (2005), linking the Nuba Mountains in the west with the White Nile in the east (Gunn, 1982; Fig. 6.4; Williams et al., 1982; Fig. 7.7). Virtually nothing is known about the alluvial history of the fan or about whether or not the alluvial channels that flow eastwards across the fan are still active. In order to provide some initial age estimates for the channels, we examined three alluvial sites in the distal portion of the fan. The first alluvial site (S4) was a shallow well dug in a seasonally flooded depression between two vegetated and stable sand dunes (Plate 1 ), and provided three freshwater shell samples and one charcoal sample from depths between $75 \mathrm{~cm}$ and $1.7 \mathrm{~m}$, which gave AMS ${ }^{14} \mathrm{C}$ ages ranging from modern to 200 years 

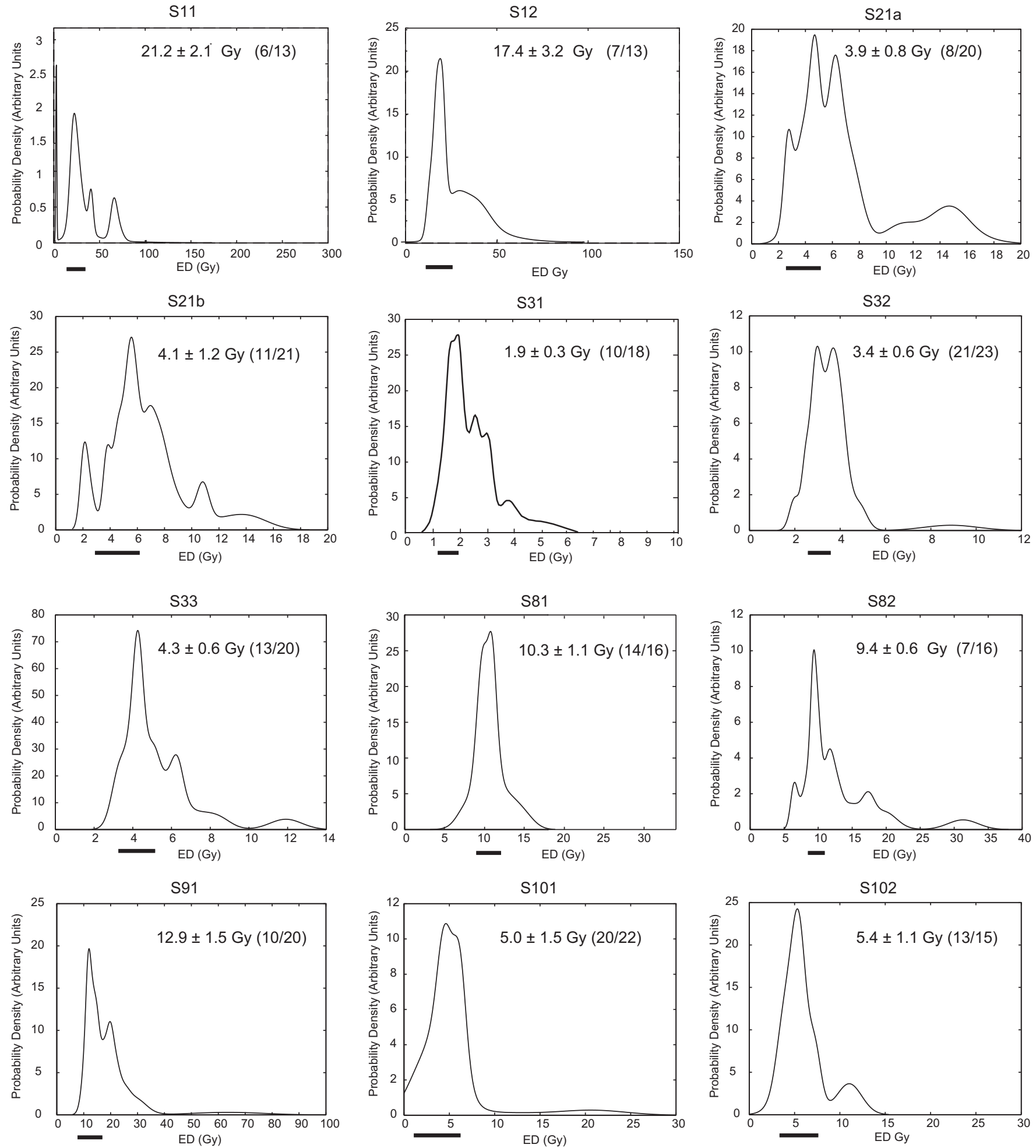

Fig. 5. Probability density plots for samples $\mathrm{S}$ (southern group). The EDs shown are determined as described in the text and Fig. 4 . The heavy black lines under the horizontal axes indicate the range of the EDs selected for the age calculation and the numbers after the ED value the number of aliquots used in the calculation/the total number of accepted aliquots.

BP (Fig. 2a; Table 3). The second site (S5) lay $3 \mathrm{~km}$ to the north of S4 and was a well $4.75 \mathrm{~m}$ deep. Three shell samples of the amphibious mollusca Pila wernei and Lanistes carinatus collected from moist grey sandy clay just excavated from the well yielded calibrated AMS ${ }^{14} \mathrm{C}$ ages of $1.0 \mathrm{kyr}, 1.1 \mathrm{kyr}$ and $1.7 \mathrm{cal} \mathrm{kyr}$ (Fig. 2a, Table 3$)$. At the

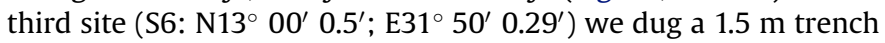

next to a seasonal clay-floored channel through alternating windblown sands and alluvial fine and coarse sands and clayey sands until we reached a fragment of green bottle glass with a probable maximum age of fifty years. Previously vegetated and stable dunes were encroaching upon the channel, which had become much narrower in this short time (see schematic diagram Fig. 2b). The 

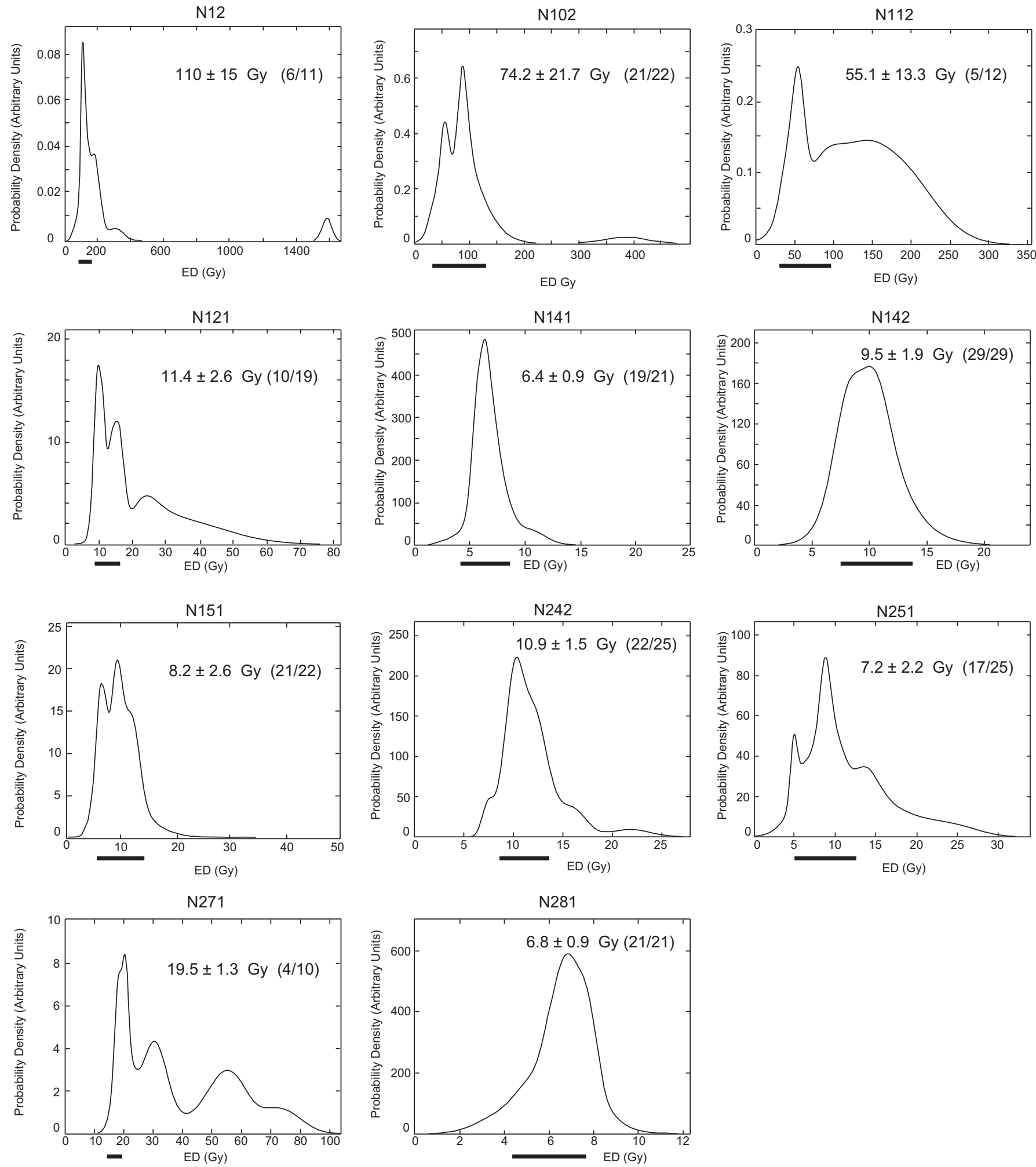

Fig. 6. Probability density plots for samples $\mathrm{N}$ (northern group). The EDs shown are determined as described in the text. The heavy black lines under the horizontal axes indicate the range of the EDs selected for the age calculation and the numbers after the ED value the number of aliquots used in the calculation/the total number of accepted aliquots.

channel was lined with over $2.1 \mathrm{~m}$ of clay covered with $10-15 \mathrm{~cm}$ of loose sand. The inference to be drawn from these very young ages is that the sector of the fan investigated by us is still very active, with alluvial sedimentation rates an order of magnitude faster than those on the Holocene floodplain of the White Nile (Williams et al., 2006).

\subsection{The Khor Abu Habl dunes}

Three OSL ages of $6.6 \pm 0.9 \mathrm{kyr}, 4.8 \pm 0.9 \mathrm{kyr}$ and $2.9 \pm 0.5 \mathrm{kyr}$ for the dune site S3 on the Khor Abu Habl alluvial fan (Plate 1) are progressively older with depth and show that the dune was accreting at these times (Fig. 2b; Table 3). Within the error terms, 

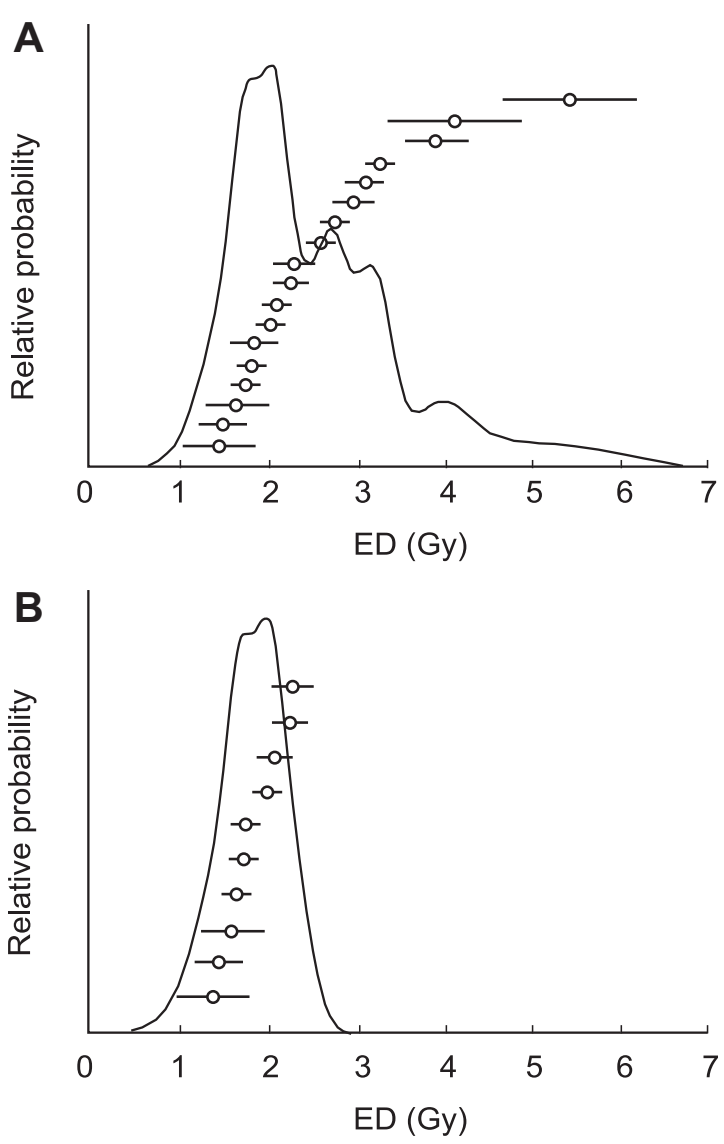

Fig. 7. Selection of ED value for use in age determination, taking sample S31 as an example. (a) Probability density plot showing ED range of all accepted small aliquots. (b) Probability density plot after outlying EDs have been removed in order to give an approximately Gaussian distribution. The weighted average of the remaining EDs is $1.9 \mathrm{~Gy}$ and weighted standard deviation $0.3 \mathrm{~Gy}$. These values are used in the age determination.

all three dates are broadly coeval with the first three of the four periods of low Holocene lake levels (8.0-6.7 kyr, 5.9-4.7 kyr, 3.6-3.0 kyr, 0.7-0.6 kyr) identified by Verschuren et al. (2009) at Lake Challa, a crater lake on the eastern flank of Mt. Kilimanjaro. Taking due account of our dating uncertainties, they also accord reasonably well with three of the six broadly defined periods of rapid Holocene climate change identified by Mayewski et al. (2004) which were characterised by polar cooling and tropical aridity. There was also a significant decrease in rainforest at 2.5-2.4 kyr in southern Cameroon probably linked to a southward shift in the ITCZ at this time (Ngomanda et al., 2009); and along the southern Dead Sea there was a sharp decrease in rainfall at $3.9 \mathrm{kyr}$ (Frumkin, 2009), suggesting that this arid phase may have been widespread.

With the abrupt return of the summer monsoon at 15.0-14.5 kyr (Williams et al., 2006), the White Nile flooded its valley to a maximum elevation of $382 \mathrm{~m}$ at and north of Esh Shawal (Fig. 2a). The $382 \mathrm{~m}$ shoreline is clearly evident in the scalloped margins of desert dunes that were active until that time (Williams, 2009). It seems likely that these dunes were also active during the arid LGM. The dates discussed above show that sand dunes in the lower White Nile valley, thought to have formed during the late Pleistocene (Williams, 1968; Adamson et al., 1982) and later stabilised by vegetation growth during the warm wet early Holocene (Williams, 1968; Adamson et al., 1974, 1982; Clark, 1989), have been reactivated at intervals during the mid and late Holocene and have developed through vertical accretion (Fig. 2b).

\subsection{The late Pleistocene and Holocene floodplain west of the White Nile}

There is no published information about the age of the alluvial plains immediately west of the White Nile. Two sites north of the town of Ed Dueim (Fig. 2a) and west of the White Nile furnished some additional information. A sample of freshwater gastropod shells collected from 0 to $15 \mathrm{~cm}$ in trench S8 gave an age of 4.5 cal kyr (Fig. 2a; Table 3), which is stratigraphically consistent with the two OSL ages of $9.8 \pm 1.1 \mathrm{kyr}$ and $13.3 \pm 0.9 \mathrm{kyr}$ at depths of $35-42 \mathrm{~cm}$ and $89-96 \mathrm{~cm}$, respectively (Fig. 2a). The OSL ages obtained on the cross-bedded sands in the White Nile palaeochannel sites S8 and S9 indicate times of high-energy flow towards $27.8 \pm 3.2 \mathrm{kyr}$ at site S9, and again at $13.3 \pm 0.9 \mathrm{kyr}$ and $9.8 \pm 1.1 \mathrm{kyr}$ at site S8. The scale of the cross-beds at site S9, with individual units up to a metre high and tens of metres wide, indicates very high-energy flow in a wide bed-load river at that time. The cross-beds at S8 are on a scale of decimetres and indicate much reduced flow velocities.

Lake Challa, located on the eastern flank of Mt. Kilimanjaro, was very high during 10.5-8.5 kyr (Verschuren et al., 2009), consistent with very wet conditions in the White Nile headwaters at this time. However, we also obtained two OSL ages of $9.9 \pm 2.0 \mathrm{kyr}$ and $9.0 \pm 2.8 \mathrm{kyr}$ from the north-south aligned Qoz Abu Dulu at site S10 located $75 \mathrm{~km}$ northwest of Khartoum (Fig. 2a), which may indicate a brief return to aridity during an otherwise moist interval. One possibility is that during times of more seasonal Nile flow, sands were blown out from exposed sandy point-bars in winter by strong northerly winds to form source-bordering dunes that became incorporated into the Qoz Abu Dulu.

Aggradation by the White Nile ceased by about 4500 years ago, either as a result of incision by the river and/or a reduction in river discharge linked to a reduction in summer rainfall, for both of which there is independent evidence (Williams et al., 2006; Williams, 2009). Two calibrated ages of $418 \pm 57$ (site S7: $14^{\circ} 03^{\prime} 53.4^{\prime} \mathrm{N} ; 32^{\circ} 14^{\prime} 09.6^{\prime} \mathrm{E}$ ) and $251 \pm 72$ (site S8, Fig. 2a; Table 3) for surface fragments of the Nile oyster Etheria elliptica are much more likely to reflect transport by humans than a belated return to very high flood levels at the end of the Little Ice Age, for which there is no other evidence.

\subsection{White Nile $386 \mathrm{~m}$ beach ridge}

Williams et al. (2003) identified a finely laminated green clay over a metre thick at a depth of $5 \mathrm{~m}$ (373 m elevation) in a trench east of Esh Shawal village on the White Nile right bank (Fig. 2a). The alluvial deposits above the green clay consisted of fine sands and sandy clays dated using multiple grain OSL and TL measurements on quartz to between $15 \mathrm{kyr}$ and >240 kyr, capped by a dark greybrown cracking clay of terminal Pleistocene-early Holocene age. Williams et al. (2003) interpreted the fissile green clay as lacustrine and traced it eastwards at depth for $9.7 \mathrm{~km}$ to an elevation of $381.4 \mathrm{~m}$, where it was $118 \mathrm{~cm}$ thick. Roughly $50 \mathrm{~km}$ to the south of Esh Shawal, near the town of Rabak, in latitude $13^{\circ} 15^{\prime} \mathrm{N}$ (Fig. 2a), satellite imagery shows a well-defined beach ridge at $386 \mathrm{~m}$ elevation to the east of the present river (Plate 1). The horizontal gradient suggested a former lake. Mapping of the $386 \mathrm{~m}$ break of slope, first identified by R.H. Gunn during soil surveys in 1952-54 (Sir Alexander Gibb and Partners, 1954; Gunn, 1982) and of the shoreline where present, showed that the putative lake may have been up to $70 \mathrm{~km}$ wide and over $500 \mathrm{~km}$ in length. This interpretation was based upon the unproven assumption that the finely laminated green clays ( $>240 \mathrm{kyr}$ ), which attained at least $381.4 \mathrm{~m}$ in elevation, were the deep-water equivalent of the $386 \mathrm{~m}$ beach ridge. However, no direct ages were then available from the beach ridge. 
In 2006 we sought to remedy this deficiency. Samples of sand for luminescence dating were collected from the beach ridge near Jebelein village. Two OSL ages came from a gully section $3 \mathrm{~km}$ east of Jebelein and just $23 \mathrm{~m}$ west of the $30 \mathrm{~m}$ high granite inselberg known locally as Jebel Hawaja (Arabic for saddle). The gully section $\mathrm{S} 1$ at $394 \mathrm{~m}$ surface elevation consisted of alternating gravels and coarse feldspathic and quartz sands (Fig. 2a) and gave an age of $27.5 \pm 2.7 \mathrm{kyr}$ at a depth of $110 \mathrm{~cm}$ and of $14.5 \pm 1.6 \mathrm{kyr}$ at a depth of $50 \mathrm{~cm}$ (Table 3). Section S2 was a backhoe trench $2.8 \mathrm{~m}$ deep located $280 \mathrm{~m}$ west of Jebel Hawaja. The two OSL samples from $60 \mathrm{~cm}$ depth near the top of a gravelly sandy clay gave ages of $3.1 \pm 0.6 \mathrm{kyr}$ and $3.0 \pm 0.9 \mathrm{kyr}$, and provide a minimum age for the Neolithic Nubian Sandstone grindstone recovered from $15 \mathrm{~cm}$ lower in the section, i.e., at $75 \mathrm{~cm}$ depth. Disturbance from termite burrows in the upper portion of the underlying gravel unit made it impossible to obtain a reliable OSL age for this unit.

The gravel and sand composing the beach embankment is locally derived from weathering of the neighbouring granite inselbergs, and only extends to a maximum of about $10 \mathrm{~km}$ to the north and south of the inselbergs. Wave action has worked the weathered gravel, which is highly rounded, and deposited it in distinct ridges. In light of the fluvial sediments with an OSL age of $27.8 \pm 3.2$ kyr at site S9 north of Ed Dueim, that indicated very highenergy flow in the White Nile at this time, there may also have been a contribution of coarse bed-load sediment from the river. Today, an alluvial fan up to $2 \mathrm{~m}$ thick flanks the granite inselberg and extends out over the adjacent beach ridge, but does not reach the S2 site. Field observations at site S2 showed a decrease in gravel content and an increase in sand and clay content from the base upwards, consistent with lake retreat, a decrease in wave energy and local reworking of beach sand by wind. The OSL ages obtained from S1 are thus more likely to reflect the time of ultimate beach reworking rather than dating the initial time of deposition of the original beach gravels. A further complicating factor is the slow but sustained influx of coarse and fine grains of quartz and feldspar derived from weathering and erosion of Jebel Hawaja. If we accept the OSL ages at face value, it is clear that the $386 \mathrm{~m}$ gravel beach ridge which extends east of the White Nile northwards from $11^{\circ} 12^{\prime} \mathrm{N}$ to $13^{\circ} 15^{\prime} \mathrm{N}$ is a relatively youthful feature of the landscape formed during a time in the very late Pleistocene when the White Nile was transporting a substantial load of sand and gravel. The two OSL ages of $27.5 \pm 2.7 \mathrm{kyr}$ and $14.5 \pm 1.6 \mathrm{kyr}$ may point to two phases of beach ridge formation: one synchronous with the interval of high-energy flow evident at site S9 west of the White Nile (OSL age: $27.8 \pm 3.2 \mathrm{kyr}$ ), and the other marking the 15.0-14.5 kyr abrupt return of the summer monsoon reflected in overflow from the Ugandan headwaters of the White Nile (Williams et al., 2006) and from Lake Tana near the Ethiopian headwaters of the Blue Nile (Lamb et al., 2007). However, there is no sign of any depositional hiatus at the beach ridge site $\mathrm{S} 1$ and it seems very unlikely that two transgressions would have resulted in a single beach ridge. Pending future attempts to obtain exposure ages for the beach ridge, this question is best left open.

The apparent absence of the $386 \mathrm{~m}$ beach ridge north of Rabak requires explanation. An observation made in 1904 by the distinguished hydraulics engineer Sir William Willcocks may provide an answer. Willcocks (1904) pointed out that at the Abu Zeid ford near Rabak there is a 'serious obstacle to navigation when the river is low, in the shape of a very broad sheet of shingle studded thick with freshwater oysters. This bar is $6 \mathrm{~km}$ long, as hard as stone, and has in very low summer supplies [of water] a depth of water over it of only $50 \mathrm{~cm}^{\prime}$ (Willcocks, 1904, p. 42). At present at low water the river reaches an elevation of $374 \mathrm{~m}$ at Rabak and $378 \mathrm{~m}$ when in flood. It is entirely possible that a once higher and more extensive lithified gravel bar in the natural channel constriction at Abu Zeid may have acted as a dam for the $386 \mathrm{~m}$ White Nile shortly after flow into the White Nile headwaters resumed from Lake Victoria and before the Sudd swamps had time to become re-established and act as a physical filter for the White Nile. This interpretation would explain the apparent absence of any gravel beach ridges north of Rabak.

However, it is also possible that any beach ridge that may have existed further north has been obscured by colluvium shed from the Manaqil Ridge to the east. There is possible evidence of this in the form of a sandy ridge at $386 \mathrm{~m}$ elevation which can be traced on the ground north of Rabak as far north as $13^{\circ} 24^{\prime} \mathrm{N}$. A soil pit located at $13^{\circ} 23^{\prime} 30^{\prime} \mathrm{N}, 32^{\circ} 43^{\prime} 40^{\prime \prime} \mathrm{E}$, sampled by one of us (MAJW) on 5.2.64, had a surface elevation of $387 \mathrm{~m}$. The upper $45 \mathrm{~cm}$ contained over $50 \%$ fine rolled quartz pebbles in a matrix of sandy clay and were underlain by at least $155 \mathrm{~cm}$ of gravelly sandy clay, within which there were sub-angular quartz clasts up to $12 \mathrm{~cm}$ in diameter (Hunting Technical Services Limited, 1964). The $15 \mathrm{kyr}$ buried shell bed near Esh Shawal $50 \mathrm{~km}$ north of site S1 never exceeded $382 \mathrm{~m}$ in elevation

\subsection{Summary: late Quaternary environments in the White Nile valley}

The youngest radiocarbon ages obtained from the 2006 reconnaissance came from the alluvial sediments in the distal reaches of the Khor Abu Habl fan and showed that the channels have been actively aggrading from at least two thousand years ago until the present. The vegetated and stable dunes that rise from the alluvial swales contain evidence of a longer history. Of the twelve samples from the White Nile valley and main Nile valley northwest of Khartoum dated by OSL, five represent times of increased Holocene dune activity at $9.9 \pm 2.0 \mathrm{kyr}, 9.0 \pm 6.6 \mathrm{kyr}, 6.56 \pm 0.9 \mathrm{kyr}$, $4.8 \pm 0.9 \mathrm{kyr}$ and $2.9 \pm \mathrm{kyr}$. To the best of our knowledge, these are the first OSL ages obtained so far for dune activity immediately west of the White Nile (site S3) as well as for the Qoz Abu Dulu (site S10), a major north-south aligned dune situated west of the Nile. Within the limits of the dating errors, the three youngest episodes of dune activity coincide very broadly with periods of rapid climate change recognised by Mayewski et al. (2004) and characterised by polar cooling and tropical aridity, and three of the dune ages are coeval with three of the four periods of low Holocene lake levels identified at Lake Challa by Verschuren et al. (2009). Evidence from lake sediments and stable isotope studies on molluscs shows the climate became drier in NW Sudan towards $\sim 6.4 \mathrm{kyr}$ and $\sim 4.5 \mathrm{kyr}$ (Ritchie et al., 1985; Abell and Hoelzmann, 2000; Hoelzmann et al., 2000).

The two White Nile cross-bedded palaeochannel sand sites (S8 and S9) indicate times of high-energy flow towards $27.8 \pm 3.2 \mathrm{kyr}$, $13.3 \pm 0.9 \mathrm{kyr}$ and $9.8 \pm 1.1 \mathrm{kyr}$. The latter two ages accord with evidence of high White Nile flow from radiocarbon dated shell beds east of the river (Williams et al., 2006) and with the presence of a large freshwater lake in NW Sudan between $\sim 10.8 \mathrm{kyr}$ and $\sim 4.5 \mathrm{kyr}$ (Hoelzmann et al., 2000). The older age shows that the White Nile was a highly energetic river with a substantial sandy bed-load in the period preceding the Last Glacial Maximum. This had never previously been demonstrated. White Nile discharge declined at or soon after $4.5 \mathrm{kyr}$.

The OSL ages for site S2 just west of Jebelein on the eastern side of the White Nile appear straightforward. The two ages of $3.1 \pm 0.6 \mathrm{kyr}$ and $3.0 \pm 0.9 \mathrm{kyr}$ for the sandy clay samples S21a and b at site S2 are consistent with the recovery of a late Neolithic or early Iron Age grindstone from this unit and appear to represent a brief interval of slightly wetter climate known from this period and well documented both for the White Nile valley (Adamson et al., 1987; Williams, 2009) as well as for other parts of the Sudan (Mawson and Williams, 1984; Williams, 2009). 
The two samples from site S1 were more difficult to date and are harder to interpret. Our aim in attempting to obtain OSL ages for these sandy gravels was to test the hypothesis that the $386 \mathrm{~m}$ beach gravels were $<240 \mathrm{kyr}$ in age (Williams et al., 2003). The two ages of $14.5 \pm 1.6 \mathrm{kyr}$ and $27.5 \pm 2.7 \mathrm{kyr}$ may denote some disturbance of the original beach gravels and incorporation of younger interstitial sand and/or reworking of the original beach at intervals during the late Pleistocene and early Holocene. The $27.5 \pm 2.7 \mathrm{kyr}$ OSL age for the lower beach ridge sample at site $S 1$ coincides very well with the $27.8 \pm 3.2 \mathrm{kyr}$ interval of very high-energy flow at site S9 west of the White Nile. The $14.5 \pm 1.6 \mathrm{kyr}$ OSL age for the upper beach ridge sample at site $\mathrm{S} 1$ falls squarely within the time when the summer monsoon became intensified across tropical Africa (Williams et al., 2006; Lamb et al., 2007; Gasse et al., 2008; Williams, 2009).

Separating these two intervals of high flow in the White Nile was the arid Last Glacial Maximum (here defined as the time of maximum global ice volume as deduced from the marine oxygen isotope record, or $21 \pm 2 \mathrm{kyr}$ : Mix et al., 2001) when the Sahara was even drier than today and desert dunes reached as far south as latitude $12^{\circ} \mathrm{N}$ (Grove, 1980; Mainguet et al., 1980; Talbot, 1980). It was also a time when Lakes Victoria, Albert and Edward in Uganda were dry or at very low levels and no longer flowing into the White Nile (Beuning et al., 1997; Lærdal et al., 2002; Stager and Johnson, 2000, 2008; Stager et al., 1986, 2002). The resumption of overflow from Lakes Victoria and Albert at 15-14.5 kyr (Talbot and Williams, 2009) would have involved a very different flow regime for the White Nile before re-establishment of the Sudd swamps in southern Sudan. Once the swamps had developed anew, they would have effectively impeded the passage of anything coarser than clay. We hypothesise that the 30-25 kyr White Nile had a far more seasonal flow regime (buffered today by the Sudd) and was transporting gravel and sand in what were possibly a series of hydraulically efficient anabranching channels (Nanson and Knighton, 1996) flowing across a semi-arid and sparsely vegetated landscape. It is also possible that aeolian reworking of the sandy gravels may have led to incorporation of local sands and wind-blown silts within the porous gravels during intervals of drought and lack of surface vegetation cover.

\section{OSL and AMS ${ }^{14} \mathrm{C}$ ages from the northern sites}

\subsection{Previous work}

According to Butzer (1980), Nile sediments in southern Egypt were laid down during very high floods between 14500 and 12000 ${ }^{14} \mathrm{C}$ years BP, with shorter intervals of deposition at $9000-8400$ and $8000{ }^{14} \mathrm{C}$ years BP. Subsequent work on Holocene river behaviour in northern Sudan was conducted as part of the Northern Dongola Reach Survey (NDRS) led by Derek Welsby of the British Museum, in which the archaeological survey and the geomorphological work were all carried out on the valley floor to the east of the modern Nile. Along the northern Dongola reach of the Nile, Woodward et al. (2001) and Welsby et al. (2002) have obtained ten OSL ages and two radiocarbon ages that range from $7.5 \mathrm{kyr}$ to $0.5 \mathrm{kyr}$ for three former Nile channels, floodplains and associated archaeological sites. The latter range from Neolithic (7.5 kyr to $5.7 \mathrm{kyr}$ ) through Kerma (4.5 kyr to $3.5 \mathrm{kyr}$ ), and New Kingdom/Kushite (3.1-2.8 kyr) to PostMeroitic (0.5 kyr). The Kerma sites are concentrated along the margins of the palaeochannels up to $15 \mathrm{~km}$ from the present river. Two major palaeochannels (the Hawawiya and the Alfreda) converge downstream into the present-day Seleim Basin. The Hawawiya Nile channel ceased to flow during or soon after 3.7-3.6 kyr (Woodward et al., 2001). The youngest OSL ages show that both the Alfreda and the Seleim Nile palaeochannels were active until at least $2.8 \mathrm{kyr}$ and possibly on occasion until about $1.5 \mathrm{kyr}$.

\subsection{Nile terraces, palaeochannels and floodplains}

The vast majority of the sites sampled in 2005 and shown in Fig. 3 are located to the west of the modern Nile. A series of eroded remnants of much older Nile channel deposits and floodplains west of the main Nile (Figs. 3 and 4) have OSL ages of $145 \pm 20 \mathrm{kyr}$ (N12 ), $83 \pm 24 \mathrm{kyr}(\mathrm{N} 10-2), 32.3 \pm 8.0 \mathrm{kyr}(\mathrm{N} 11-2)$ and $11.0 \pm 0.7 \mathrm{kyr}$ (N27-1), with one much younger age of $3.9 \pm 0.5 \mathrm{kyr}(\mathrm{N} 28-1)$ (Fig. 4; Table 4). Radiocarbon ages range from $>53.1$ kyr to 5.2 kyr (Fig. 4; Table 4), with seven of the ages between $8.9 \mathrm{kyr}$ and $5.5 \mathrm{kyr}$ indicating widespread flooding and sediment deposition at this time.

\subsection{Holocene palaeolake in the Qaab Depression}

The Qaab Depression (Plate 2; Fig. 3) lies $\sim 15 \mathrm{~km}$ west of the main Nile from $19^{\circ} 04^{\prime}$ to $19^{\circ} 27^{\prime} \mathrm{N}$ and from $30^{\circ} 05^{\prime}$ to $30^{\circ} 19^{\prime} \mathrm{E}$, and is aligned $\sim 30 \mathrm{~km}$ from north to south and $\sim 15 \mathrm{~km}$ from east to west, an area of $\sim 450 \mathrm{~km}^{2}$. Lacustrine silts rich in both diatom frustules and freshwater gastropod shells (mainly Melanoides tuberculata) cover the floor of the depression. The gastropods have calibrated radiocarbon ages of $10.1 \mathrm{kyr}$ near the base of the silts and 7.9-7.4 kyr near the top (Table 4, sites N4, N8 and N16). The diatoms in the lake silts at site $\mathrm{N} 7$ were analysed every $10 \mathrm{~cm}$ from the surface to a depth of $60 \mathrm{~cm}$, at which point they gave way to weathered Nubian Sandstone. The dominant species was Aulacoseira granulata, a taxon common in the upper Nile and one that favours especially turbid conditions (Stager et al., 1997, 2003; Stager and Johnson, 2000, 2008) and is widespread globally. It is often prevalent in deep flowing waters. On the satellite imagery (Plate 2) a narrow and now defunct overflow channel links the palaeolake with an early Holocene branch of the main Nile. The dominance of $A$. granulata also indicates a connection between the former lake and the early Holocene Nile. A modern analogue is provided by the Murray River and its adjoining wetlands in southeastern Australia. A. granulata is the dominant alga in the Murray River (Hötzel and Croome, 1996; Tibby and Reid, 2004) and in those wetlands that receive major inputs of water from the Murray, but not in other wetlands since it does not survive in low turbulence environments (Reid and Ogden, 2009).

\subsection{Summary: late Quaternary environments in the main Nile valley}

OSL ages for Nile and tributary wadi alluvium range from $145 \pm 20 \mathrm{kyr}, 83 \pm 24 \mathrm{kyr}, 32 \pm 8 \mathrm{kyr}$ and $11.0 \pm 0.7 \mathrm{kyr}$ to $3.9 \pm 0.5 \mathrm{kyr}$, and radiocarbon ages range from $>53.1 \mathrm{kyr}$ to $5.2 \mathrm{kyr}$ (Fig. 4; Table 4). Seven of the ages were between $8.9 \mathrm{kyr}$ and $5.5 \mathrm{kyr}$, indicating widespread sediment deposition at this time. One OSL age of $6.5 \pm 2.1 \mathrm{kyr}$ (N151) for a red-brown fossil soil developed on wind-blown sands is also consistent with a wetter climate at this time. The more recent of these ages have their counterparts in the White Nile valley, where high floods are evident at 28-26 kyr, $13.3 \pm 0.9 \mathrm{kyr}$ and $9.8 \pm 1.1 \mathrm{kyr}$. Shell-bearing lake silts are widespread west of the main Nile and were deposited during wetter intervals between $10 \mathrm{kyr}$ and $6.8 \mathrm{kyr}$. There were brief intervals of wind-blown sand accession at $9.5 \mathrm{cal} \mathrm{kyr,} 7.9 \pm 1.1 \mathrm{kyr}$ and soon after $6.8 \mathrm{kyr}$, evident in the form of aeolian sand units above and beneath diatomaceous lake silts (Fig. 4). The latter age is coeval with a phase of dune accretion at $6.5 \mathrm{kyr}$ in the White Nile valley. Both the White Nile and main Nile show evidence of reduced flooding and more localised alluvial deposition after about $4.5 \mathrm{kyr}$, when the climate became much drier across the southern Sahara. The 9.5 cal kyr charcoal age at site $\mathrm{N}-25$ is similar to the OSL ages of $9.9 \pm 2.0 \mathrm{kyr}$ and $9.0 \pm 2.8$ kyr for dune site S10 on the Qoz Abu Dulu, and is consistent with brief phases of aridity within an otherwise moist 
climatic interval. Fontes et al. (1985) noted rapid hydrological changes in Holocene lakes in the northern Sahara, which fluctuated between fresh and highly saline within short intervals.

\section{Discussion}

Times of high Nile flow during the Quaternary were marked by the accumulation on the floor of the eastern Mediterranean of clastic muds rich in continental organic matter (Ducassou et al., 2008) and of highly organic sapropels (Rossignol-Strick, 1985, 1999; Mercone et al., 2001). A core collected from a depth of 4-6 $\mathrm{m}$ at Esh Shawal immediately east of the present White Nile and ca. $250 \mathrm{~km}$ south of Khartoum indicates high flow at $166 \pm 30 \mathrm{kyr}, 206 \pm 40 \mathrm{kyr}$ and $210 \pm 30 \mathrm{kyr}$, broadly coincident with sapropel units S6, S7 and S8, respectively (Williams et al., 2003). The OSL age obtained here for high-level Nile alluvium at $83 \pm 24$ kyr coincides with the $81 \mathrm{kyr}$ age for sapropel S3 and the older date of $145 \pm 20 \mathrm{kyr}$ overlaps slightly with sapropel S6 (Lourens et al., 1996), although the correlation is weak. Given the broad error range of these OSL ages, any correlation with the sapropel units is necessarily highly tentative, but is in each case consistent with higher Nile flow and a stronger monsoon at these times. Site $\mathrm{N} 1$ gave a ${ }^{14} \mathrm{C}$ age $>53 \mathrm{kyr}$ and the two unbroken Nile mussel shells embedded in fine gravels rich in agates at site N17

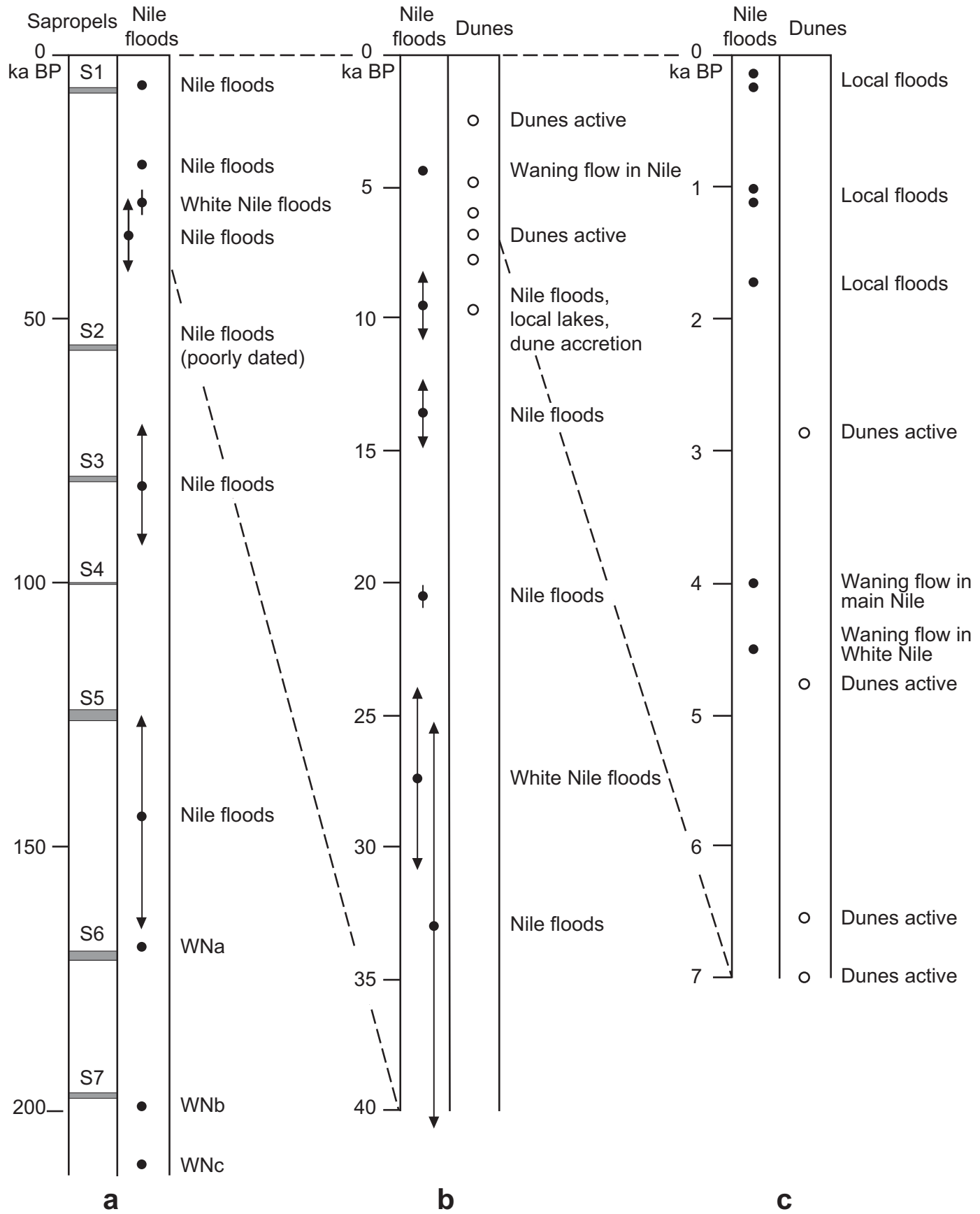

Fig. 8. (a) Relationship between Nile floods (0-200 kyr) (Williams et al., 2003, 2006; Williams, 2009 [WN a, b,c]; this work) and times of sapropel accumulation in the eastern Mediterranean (after Lourens et al., 1996). (b) Late Quaternary Nile floods, Sudan (0-40 kyr) (this work) and phases of dune accretion (this work) west of the White Nile and main Nile. (c) Holocene floods and phases of dune accretion on the distal Khor Abu Habl fan just west of the White Nile, Sudan (this work, error terms not shown). 
gave ${ }^{14} \mathrm{C}$ ages $>40 \mathrm{kyr}$. These episodes of high Nile flow may be coeval with sapropel S2 (55 kyr: Lourens et al., 1996) but this must remain speculative. Sapropel 5 was synchronous with a prolonged wet phase at $\sim 125 \mathrm{kyr}$ at Kharga Oasis in the Western Desert of Egypt (Kieniewicz and Smith, 2007).

Two phases of high flow in the main Nile have ages of $32 \pm 8 \mathrm{kyr}$ and $20.7 \pm 0.2 \mathrm{kyr}$ and an interval of very high-energy high flow in the White Nile is evident at 30-25 kyr. All three ages fall within pluvial intervals recognised on independent evidence by Gasse (2000) and by Ducassou et al. (2008). The 30-25 kyr time of high White Nile flow has not previously been identified. Two cores from Lake Albert in Uganda contain palaeosols dated to 20.7-17.7 kyr and $16.6-15.1 \mathrm{kyr}$, with intervals of high lake level before $20.7 \mathrm{kyr}$ and after $15.1 \mathrm{kyr}$ evident in the ${ }^{87} \mathrm{Sr} /{ }^{86} \mathrm{Sr}$ values (Williams et al., 2006; Talbot and Williams, 2009; Williams and Talbot, 2009). The older of the two palaeosols coincides with the Last Glacial Maximum when much of equatorial Africa was very much drier and colder than today
(Johnson et al., 1996; Gasse et al., 2008). It was also a time when Lakes Victoria, Albert and Edward were dry or at very low levels and no longer flowing into the White Nile (Beuning et al., 1997; Lærdal et al., 2002). During the LGM, dunes were active along the southern margins of the Sahara to within at least $12^{\circ} \mathrm{N}$ of the equator at this time, a southward extension of the desert approaching $500-800 \mathrm{~km}$ (Grove, 1958; Grove and Warren, 1968; Mainguet et al., 1980; Fig. 2.6; Talbot, 1980; Fig. 3.1; Nichol, 1991; Swezey, 2001). Nichol (1999) noted that well before the LGM, linear dunes were active in areas now supporting tropical lowland rainforest in west and central Africa]. In the Bale Mountains of Ethiopia up to $180 \mathrm{~km}^{2}$ may have been glaciated at this time, with a central ice cap of at least $30 \mathrm{~km}^{2}$ (Osmaston et al., 2005), while less well-dated glacial moraines and periglacial deposits close to the Blue Nile headwaters in the Semien Highlands of Ethiopia point to colder conditions ( $4-8^{\circ} \mathrm{C}$ cooler) and a lowering of the upper timber line by $\sim 1000 \mathrm{~m}$ during the LGM (Williams et al., 1978; Hurni, 1982).

\section{a $27 \mathrm{ka}$}

$\mathrm{N}$

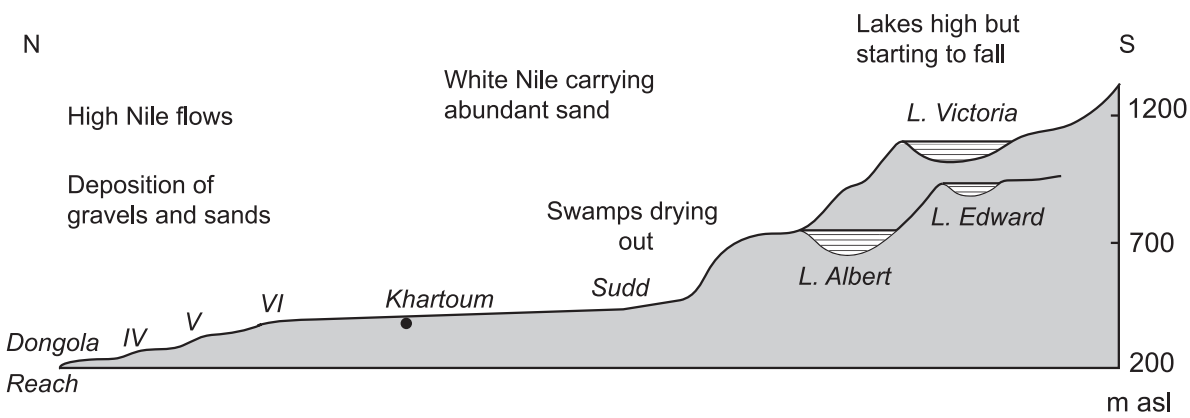

b $18 \mathrm{ka}$

N

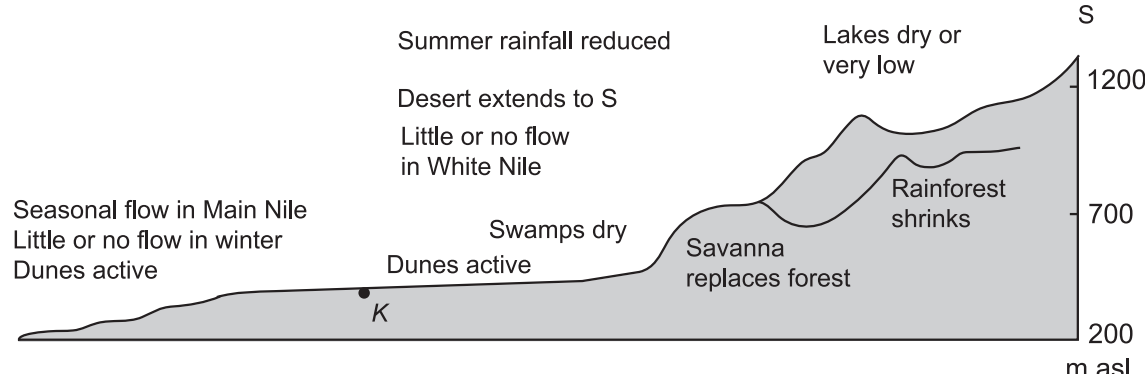

C 9 ka

N

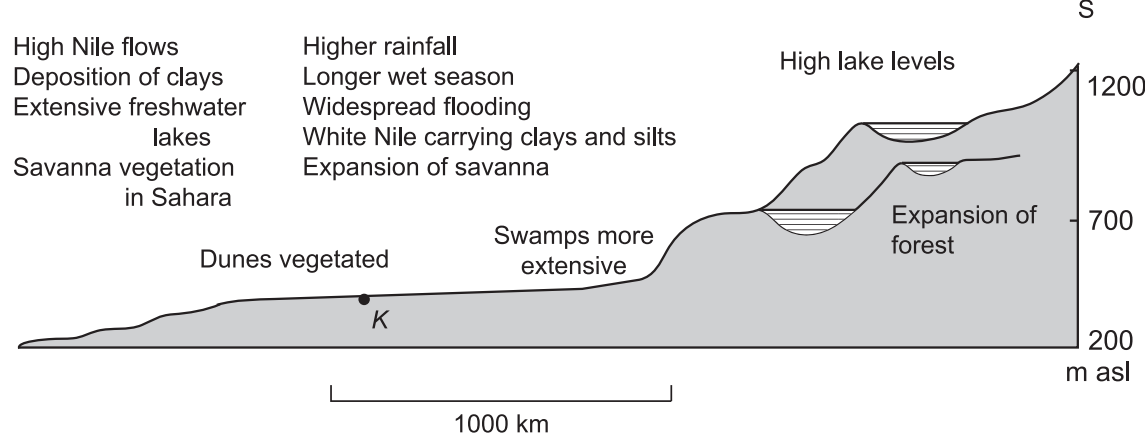

Fig. 9. Environmental changes in the White Nile basin and main Nile valley, northern Sudan during the very late Pleistocene (27 kyr), the Last Glacial Maximum (18 kyr) and the Early Holocene (9 kyr). K is Khartoum at the Blue and White Nile confluence; IV, V and VI are the 4th, 5th and 6th cataracts, respectively. 
A return to wet conditions began as early as 14-15 kyr (Johnson et al., 1996), and is evident in the sudden overflow of water from the Ugandan lakes into the upper White Nile (Williams et al., 2006), overflow from Lake Tana into the Blue Nile in Ethiopia (Lamb et al., 2007), widespread flooding by the 'wild Nile' in Egypt (Butzer, 1980), high lake levels in the uplands of Tibesti (Faure, 1969; Maley, 2000, 2004) and Jebel Marra (Williams et al., 1980; Williams, 2009), dune stabilization in the Sahara (Swezey, 2001), and a sudden reduction in dust flux from the Chad basin into the Atlantic (deMenocal et al., 2000), which showed that the African Humid Period began suddenly at $14.8 \mathrm{kyr}$ and ended abruptly at $5.5 \mathrm{kyr}$, interrupted only by a return to aridity during the Younger Dryas (YD) Chronozone (ca. 12.5-11.5 kyr) (deMenocal et al., 2000; Johnson et al., 2000; Mulitza and Rühlemann, 2000; Salzmann et al., 2002). The abrupt return of the summer monsoon evident in the Nile basin at $\sim 15 \mathrm{kyr}$ (Williams et al., 2006) was of global significance, and has been recognised in India, China and Australasia (Williams et al., 2009) as well as elsewhere in Africa (Gasse et al., 2008). Global sea-level also rose very rapidly beginning $\sim 14.2 \mathrm{kyr}$ as a result of rapid highlatitude deglaciation in both hemispheres (Clark et al., 2002).

The most recent sapropel unit S1 in the eastern Mediterranean is a twofold unit and has been precisely but not necessarily accurately dated. The upper unit is bracketed by two dates of 9.9 and $8.9 \mathrm{kyr}$, and the lower unit by two dates of 13.7 and $12.4 \mathrm{kyr}$ (RossignolStrick et al., 1982), so that the single calibrated radiocarbon age of $\sim 8.4 \mathrm{kyr}$ indicated by Mercone et al. (2001) is somewhat misleading. The sapropel record in the eastern Mediterranean is incomplete, with evidence of complete removal of sapropels by post-depositional oxidation (Higgs et al., 1994). These latter authors consider that formation of sapropel S1 may have ended as recently as $5 \mathrm{kyr}$, which is also when the Nile deep-sea turbidite system became inactive as a result of reduced sediment discharge from the Nile (Ducassou et al., 2009). The interval from $\sim 13.7$ to $8.9 \mathrm{kyr}$ and locally up to $5 \mathrm{kyr}$, coincides with a time when freshwater lakes were widespread across the entire Sahara (Faure et al., 1963; Faure, 1969; Williams et al., 1974, 1987; Ritchie et al., 1985; Pachur et al., 1990; Pachur and Hoelzmann, 1991; Grove, 1993; Hoelzmann, 1993a,b; Kröpelin, 1993; Jahns, 1995; Abell et al., 1996; Ayliffe et al., 1996; Pachur and Wünnemann, 1996; Hassan, 1997; Pachur and Altmann, 1997; Abell and Hoelzmann, 2000; Guo et al., 2000; Hoelzmann et al., 2000, 2001; Schild and Wendorf, 2001; Salzmann et al., 2002; Kuper and Kröpelin, 2006; Bubenzer and Riemer, 2007). This was also a time when the White Nile attained a flood level up to $3 \mathrm{~m}$ above its modern unregulated flood level (Williams and Adamson, 1974; Adamson et al., 1982).

The inception of the terminal Pleistocene and early to midHolocene humid climate in the Nile basin (Stager et al., 1997, 2003) was linked to changes in the tilt of the earth's axis, so that it was closest to the sun during the northern summer (Kutzbach and StreetPerrott, 1985). One consequence was a $7 \%$ increase in summer (JJA) insolation and a corresponding 7\% decrease in winter (DJF) insolation relative to the present, thereby strengthening the monsoon circulation, bringing more summer rain to tropical northern Africa, including the now arid southern and central Sahara. The wet phase

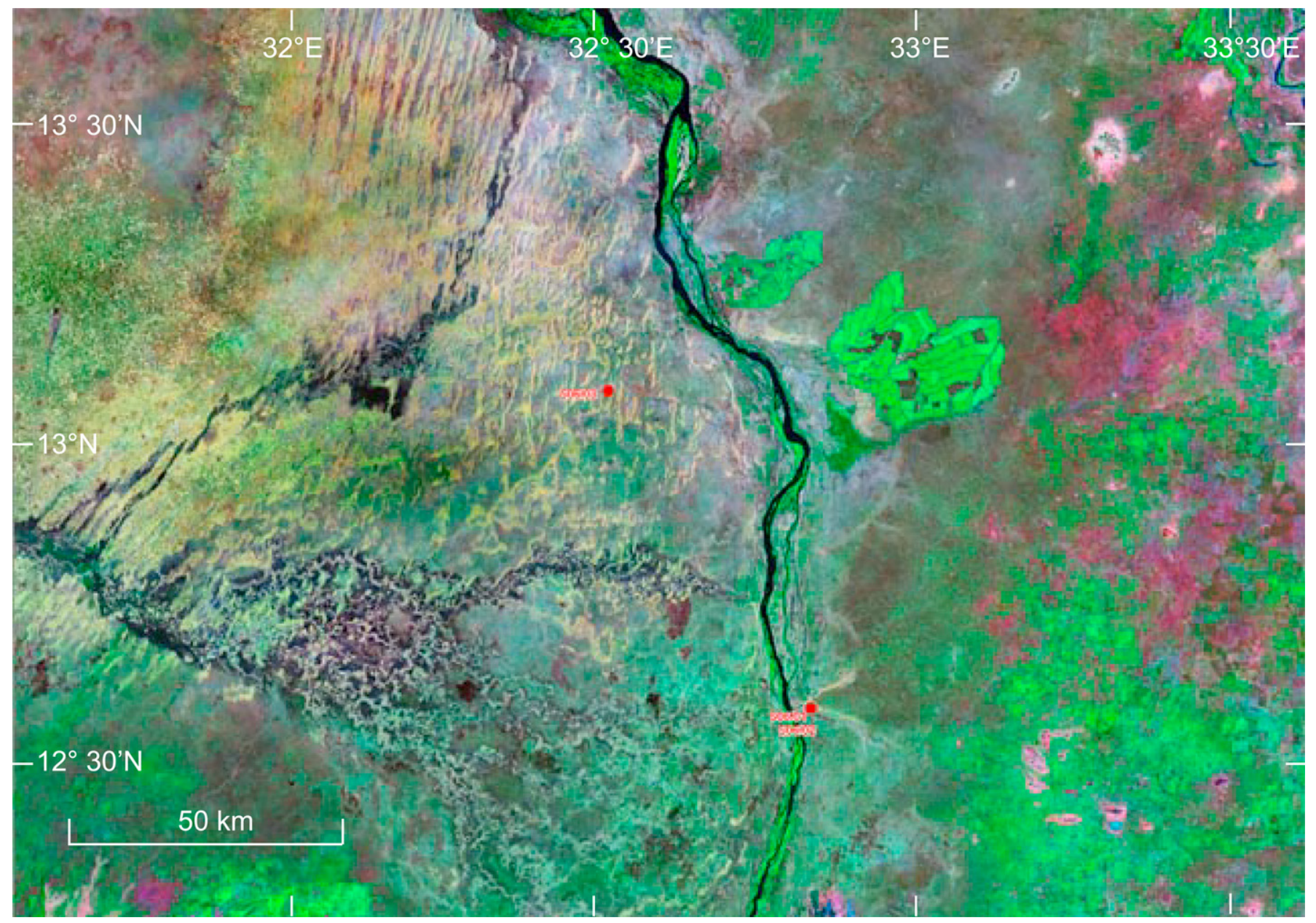

Plate 1. Satellite image showing the Khor Abu Habl alluvial fan to the west of the White Nile, the $386 \mathrm{~m}$ beach ridge to the east of the White Nile, and the location of sites $\mathrm{S} 1$, S2 and S3 (here shown as SO6/1, 2, 3) discussed in the text. 
seems to have begun quite suddenly but to have ended gradually, with lakes drying out first in higher latitudes and later in lower latitudes (Pachur et al., 1990; Pachur and Hoelzmann, 2000). The humid phase was not uniformly wet: there is good evidence at many localities of a dry period during the YD (Johnson et al., 2000; Mulitza and Rühlemann, 2000; Salzmann et al., 2002), and of additional droughts at $\sim 8 \mathrm{kyr}, 7-5.7 \mathrm{kyr}$ and $4 \mathrm{kyr}$ (Hassan, 1997; Guo et al., 2000; Mulitza and Rühlemann, 2000; Hassan et al., 2001). The Holocene sediments at Farafra in the Western Desert of Egypt show frequent oscillations in climate between 8 and $7 \mathrm{kyr}$, with the onset of dry and cold conditions at $8 \mathrm{kyr}$ (Hassan et al., 2001). At Wadi Bakht in the Gilf Kebir, $450 \mathrm{~km}$ SSW of Farafra, the change from a summer to a winter rainfall regime at 6.3-5.2 kyr marks the close of the Holocene wet phase in this area and a major change in prehistoric land use (Linstädter and Kröpelin, 2004). Salinity values in two cores from the northern Red Sea indicate much higher rainfall and freshwater runoff between 9.2 and $7.2 \mathrm{kyr}$, with a southward extension of Mediterranean winter rainfall perhaps linked to a stronger Arctic Oscillation (Arz et al., 2003). These authors found no evidence that the summer monsoon rains crossed the desert at this time, so that the presence of both tropical and Mediterranean floral elements in the Saharan uplands presumably reflects long-distance dispersal by wind and birds, as argued by Schulz (1994), contrary to the suggestion by Prentice et al. (2000) based upon a coupled climate-biosphere model.

Climate models can provide useful insights into climatic sensitivity to possible feedback processes. For example, deMenocal et al.
(2000) noted that the $14.8 \mathrm{kyr}$ onset and $5.5 \mathrm{kyr}$ close of the African Humid Period occurred in each case at a time when the summer insolation was $4.2 \%$ greater than present. They noted that this might constitute a threshold value, and argued that such abrupt climatic responses to gradual changes in insolation presupposed strongly non-linear feedback processes related to changes in land surface conditions (Hoelzmann et al., 1998) and in ocean temperature (Mulitza and Rühlemann, 2000). Prentice et al. (2000) tested a coupled climate-biosphere model and found that enhanced monsoons extended Sahelian vegetation into the Sahara consistent with a northward shift of the ITCZ, leading to a reduction in tropical rainforest - an inference which runs counter to the pollen evidence (Gasse et al., 2008), showing the need for care when using climate models. Mulitza and Rühlemann (2000) compared high-resolution alkenone-derived ocean temperature records from the SE tropical Atlantic and the NE subtropical Atlantic and found that during the YD the SSTs in the eastern tropical Atlantic reached modern levels whilst those in the subtropical NE Atlantic remained much colder than present. They concluded that the rapid changes in African monsoonal precipitation were linked to asymmetrical Atlantic SST warming, caused by a reduction in northward heat transport in the Atlantic, possibly as a result of a sudden influx of meltwater from the north.

Other factors may have helped to amplify early to mid-Holocene precipitation in the Sahara and adjacent Nile valley, including changes in albedo (Bonfils et al., 2001), expansion of lakes and wetlands (Carrington et al., 2001), and changes in sensible heat flux

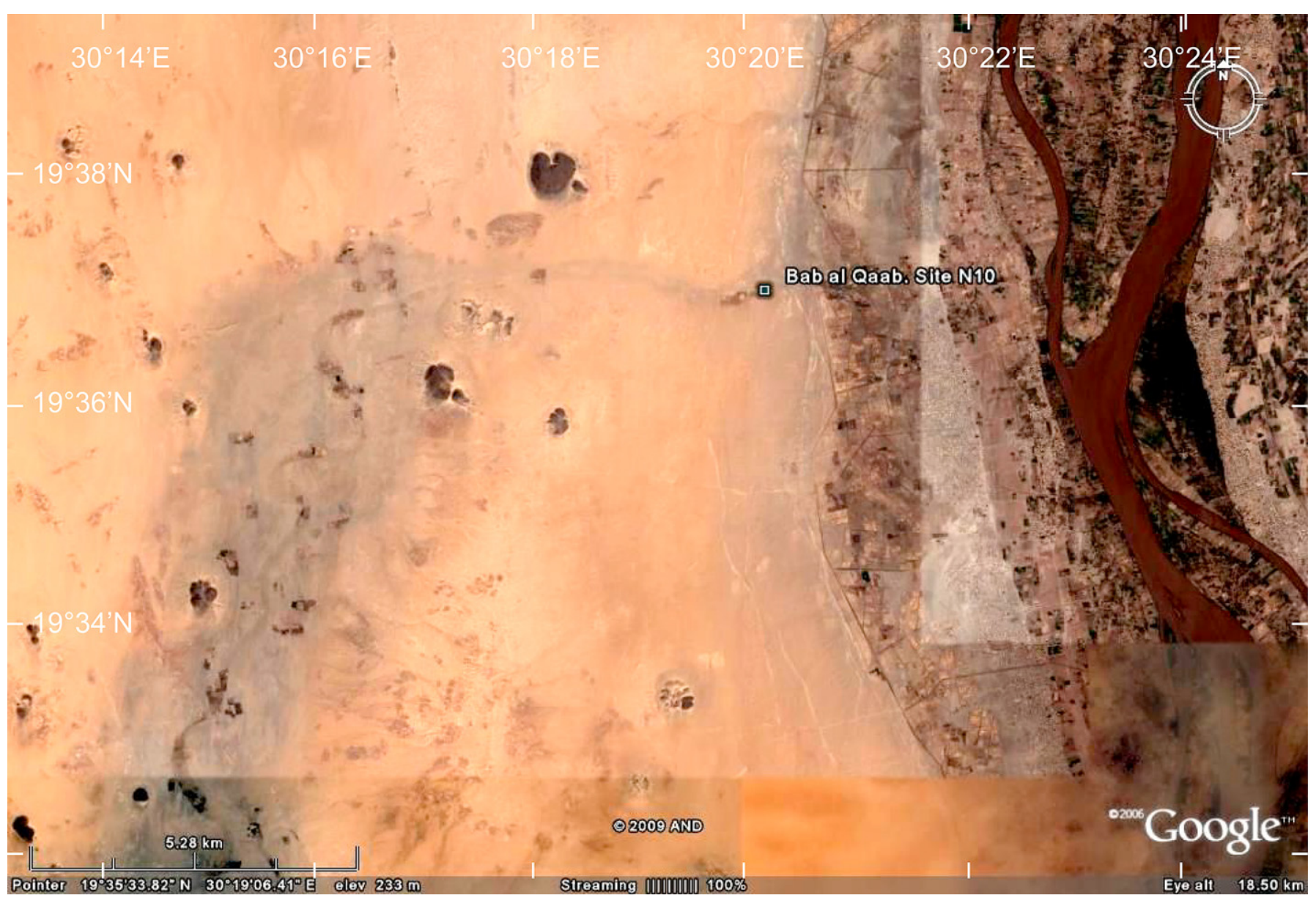

Plate 2. Satellite image of the Qaab basin west of the main Nile showing a meandering former Nile channel crossing the basin and the location of site N10 discussed in the text. The dark brown roughly circular features are low hills of Cretaceous sandstone ('Nubian Sandstone') and the broad depression into which the channel flows is lined with shallow lacustrine silts and diatomites above weathered Cretaceous sandstone. 
(Braconnot et al., 2001). Indeed, Hoelzmann et al. (1998) have argued that models that do not include biogeophysical feedback cannot account for the magnitude of the African monsoon at this time (11-6 kyr). In addition, Claussen et al. (1999) concluded that the mid-Holocene desiccation of the Sahara was linked to subtle changes in orbital geometry amplified by atmosphere-vegetation feedbacks in the subtropics. The impact of this climatic desiccation is clearly evident in the strontium isotope records from the Nile delta (Krom et al., 2002) and in the disintegration of the Old Kingdom dynasty in Egypt caused by the severe drought at $4.2 \mathrm{kyr}$ (Stanley et al., 2003), an abrupt climatic event that also precipitated the collapse of the Akkadian empire in the headwaters of the Tigris and Euphrates rivers (Cullen et al., 2000).

\section{Conclusions}

Our results very broadly confirm the link, which has sometimes been disputed, between times of high flow in the Nile and times of sapropel formation in the eastern Mediterranean (Fig. 8a), and have added important new detail (Fig. 8b) to earlier reconstructions of Nile flood history (Williams et al., 2000, 2006; Williams, 2009). Of the twelve samples from the White Nile valley dated by OSL, five represent times of increased Holocene dune activity towards 10-9 kyr, $6.6 \mathrm{kyr}, 4.8 \mathrm{kyr}$ and $2.9 \mathrm{kyr}$ (Fig. 8b and c). Within the limits of the error terms, all four episodes of dune activity coincide with periods rapid climate change and tropical aridity recognised by Mayewski et al. (2004). Flow was high in the White Nile at $28-26,13.3 \pm 0.9$ and $9.8 \pm 1.1 \mathrm{kyr}$ and began to wane soon after $4.5 \mathrm{kyr}$ (Fig. 8c). The earlier phases of Holocene dune activity appear to have been short-lived events intercalated within periods of wetter climate and higher Nile flow.

The OSL ages of $27.5 \pm 2.7 \mathrm{kyr}$ and $14.5 \pm 1.6 \mathrm{kyr}$ for the beach ridge at site $S 1$ east of Jebelein on the White Nile east bank appear to be valid but may reflect local reworking of the sandy beach gravels of the $386 \mathrm{~m}$ White Nile lake during the waning phases of the transgression and/or during drier intervals when the ground surface was bare, leading to deposition of wind-blown silts within the original beach gravels. Ages obtained for the beach deposits in the far south of the area seem to indicate a complex history of accretion, erosion, mixing and re-deposition.

The OSL ages of $3.1 \pm 0.6 \mathrm{kyr}$ and $3.0 \pm 0.4 \mathrm{kyr}$ for the sandy clay samples S21a and b at site S2 are consistent with the recovery of a late Neolithic or early Iron Age grindstone from this unit and appear to represent a brief interval of slightly wetter climate known when swamp clays accumulated on the late Holocene White Nile floodplain towards 3.2-2.8 kyr (Fig. 8c). This wetter phase is well documented for the White Nile valley (Adamson et al., 1987; Williams, 2009). The AMS ${ }^{14} \mathrm{C}$ ages obtained from the hitherto undated Khor Abu Habl Fan immediately west of the White Nile indicate active deposition by fan distributary channels between 1.7 and $1.1 \mathrm{cal} \mathrm{kyr}$ and again within the past two centuries (Fig. 8c). Conditions at the present-day mist oasis of Erkowit in the Red Sea Hills were also wetter between 1.6 and 1.8 cal kyr (Mawson and Williams, 1984; Williams, 2009).

OSL ages for Nile alluvium in northern Sudan older than $32 \mathrm{kyr}$ have large error terms. Ages between $11 \mathrm{kyr}$ and $4 \mathrm{kyr}$ are more reliable (Fig. 8a), and indicate Nile floods and episodic Nile aggradation during the early to mid-Holocene. All but one of the 15 finite AMS ${ }^{14} \mathrm{C}$ ages from the northern sites fall between $10 \mathrm{kyr}$ and $4.7 \mathrm{kyr}$, again consistent with a wetter early to mid-Holocene climate. Nine of the ten AMS ${ }^{14} \mathrm{C}$ ages from the southern area post-date the last dune-building phase and indicate a return to wetter conditions by $1.7 \mathrm{kyr}$ (Fig. 8c).

Fig. 9 is distilled from Williams et al. (2006), Williams (2009) and the present work. It summarises the environmental changes in the
White Nile basin and in the main Nile valley of northern Sudan during the very late Pleistocene $(\sim 27 \mathrm{kyr})$, the Last Glacial Maximum ( $\sim 18 \mathrm{kyr})$ and the Early Holocene ( $\sim 9 \mathrm{kyr})$. Towards $27 \mathrm{kyr}$ the lake levels in the White Nile headwaters were starting to fall and the Sudd swamps to shrink, allowing the White Nile to carry substantial volumes of sand into its lower reaches. By $18 \mathrm{kyr}$ the Uganda lakes were dry or very low, so that overflow into the White Nile had ceased. The Sudd swamps dried out. Dunes were active at least $50 \mathrm{~km}$ south of Khartoum along both banks of the lower White Nile, which was probably dry for most of the year. The Blue Nile was a highly seasonal river, as was the main Nile, which carried a bedload of coarse sand and gravel of Blue Nile provenance into northern Sudan and southern Egypt. Flow in the White Nile resumed with the abrupt return of the summer monsoon at 14.5-15 kyr, leading to overflow from the Ugandan lakes. The Sudd swamps became re-established and trapped all but the finest sediment, so that the White Nile today carries a meagre load of about two million tonnes of silt and clay. There were sporadic small lakes in presently arid northern Sudan during the early to mid-Holocene. Nile floods were very high towards $14.5-15 \mathrm{kyr}$, and were again high at $13 \mathrm{kyr}$ and at intervals from $11 \mathrm{kyr}$ to $5.5 \mathrm{kyr}$, albeit interspersed with brief intervals of dune activity. Present flood levels were attained by $4.5 \mathrm{kyr}$ and have remained modest ever since.

\section{Acknowledgements}

We thank the Australian Research Council for financial support. Particular thanks go to Dr M. Abdelrazig O.M Ahmed, Director General, Geological Research Authority of the Sudan, for his many kindnesses to us during our recent visits to the Sudan. Sayed Nagi Abdalla Mohamed, Field Manager, Danfodia Company for Contracting Roads and Bridges, Jebelein, generously allowed the use of a backhoe for excavating the deep trench at site S2. The Dams Implementation Unit (Government of the Republic of the Sudan) and Lahmeyer International $\mathrm{GmbH}$ are thanked for logistical support in northern Sudan. Professor John Prescott and Professor David Huntley provided insightful comments on the luminescence dating, and Dr John Tibby gave wise counsel on the diatom ecology. We thank Dr Philip Hoelzmann and Dr Stefan Kroepelin for their careful reviews. As always, our appreciation goes to the people of the Sudan for their unfailing courtesy, hospitality and help. This paper is dedicated to the memory of Mike Talbot who died on 6/11/ 09: generous friend, brilliant Quaternary geologist and incomparable field companion: vale.

\section{References}

Abell, P.I., Hoelzmann, P., 2000. Holocene palaeoclimates in northwestern Sudan: stable isotope studies on molluscs. Global and Planetary Change 26, 1-12.

Abell, P.I., Hoelzmann, P., Pachur, H.-J., 1996. Stable isotope ratios of gastropod shells and carbonate sediments of NW Sudan as palaeoclimatic indicators. Palaeoecology of Africa 24, 33-52.

Adamson, D.A., Clark, J.D., Williams, M.A.J., 1974. Barbed bone points from central Sudan and the age of the "Early Khartoum" tradition. Nature 249, 120-123.

Adamson, D.A., Gasse, F., Street, F.A., Williams, M.A.J., 1980. Late Quaternary history of the Nile. Nature 287, 50-55.

Adamson, D.A., Gillespie, R., Williams, M.A.J., 1982. Palaeogeography of the Gezira and of the lower Blue and White Nile valleys. In: Williams, M.A.J Adamson, D.A. (Eds.), A Land between Two Niles: Quaternary Geology and Biology of the Central Sudan. A.A. Balkema, Rotterdam, pp. 165-219.

Adamson, D.A., Clark, J.D., Williams, M.A.J., 1987. Pottery tempered with sponge from the White Nile, Sudan. African Archaeological Review 5, 115-127.

Adamson, D., McEvedy, R., Williams, M.A.J., 1993. Tectonic inheritance in the Nile basin and adjacent areas. Israel Journal of Earth Sciences 41, 75-85.

Arz, H.W., Lamy, F., Pätzold, J., Müller, P.J., Prins, M., 2003. Mediterranean moisture source for an Early-Holocene humid period in the northern Red Sea. Science $300,18-121$.

Ayliffe, D., Williams, M.A.J., Sheldon, F., 1996. Stable carbon and oxygen isotopic composition of early-Holocene gastropods from Wadi Mansurab, north-central Sudan. The Holocene 6, 157-169. 
Beuning, K.R.M., Talbot, M.R., Kelts, K., 1997. A revised 30,000-year paleoclimatic record and paleohydrologic history of Lake Albert, East Africa. Palaeogeography, Palaeoclimatology, Palaeoecology 136, 259-279.

Bonfils, C., de Noblet-Ducoudré, N., Braconnot, P., Joussaume, S., 2001. Hot desert albedo and climate change: mid-Holocene monsoon in North Africa. Journal of Climate 14, 3724-3737.

Braconnot, P., Joussaume, S., de Noblet, N., Ramstein, G., 2001. Mid-Holocene and last glacial maximum African monsoon changes as simulated within the paleoclimate modelling intercomparison project. Global and Planetary Change 26, 51-66.

Bubenzer, O., Riemer, H., 2007. Holocene climatic change and human settlement between the central Sahara and the Nile valley: archaeological and geomorphological results. Geoarchaeology 22, 607-620.

Butzer, K.W., 1980. Pleistocene history of the Nile valley in Egypt and lower Nubia. In: Williams, M.A.J., Faure, H. (Eds.), The Sahara and the Nile. Quaternary Environments and Prehistoric Occupation in Northern Africa. A.A.Balkema, Rotterdam, pp. 253-280.

Carrington, D.P., Gallimore, R.G., Kutzbach, J.E., 2001. Climate sensitivity to wetlands and wetland vegetation in mid-Holocene North Africa. Climate Dynamics 17, $151-157$.

Chylek, P., Lesins, G., Lohmann, U., 2001. Enhancement of dust source area during past glacial periods due to changes of the Hadley circulation. Journal of Geophysical Research 106, 18477-18485.

Clark, J.D., 1980. Human populations and cultural adaptations in the Sahara and Nile during prehistoric times. In: Williams, M.A.J., Faure, H. (Eds.), The Sahara and the Nile: Quaternary Environments and Prehistoric Occupation in Northern Africa. A.A. Balkema, Rotterdam, pp. 527-582.

Clark, J.D., 1989. Shabona: an early Khartoum settlement on the White Nile. In: Krzyzaniak, L., Kobusiewicz, M. (Eds.), Late Prehistory of the Nile Basin and the Sahara. Studies in African Archaeology, vol. 2. Poznan Archaeological Museum, Poznan, pp. 387-410.

Clark, P.U., Mitrovica, J.X., Milne, G.A., Tamisiea, M.E., 2002. Sea-level fingerprinting as a direct test for the source of global meltwater pulse $1 \mathrm{~A}$. Science 295, 2438-2441.

Claussen, M., Brovkin, V., Ganopolski, A., Kubatzki, C., Petoukhov, V., 1998. Modelling global terrestrial vegetation-climate interaction. Philosophical Transactions of the Royal Society of London B353, 53-63.

Claussen, M., Kubatzki, C., Brovkin, V., Ganopolski, A., Hoelzmann, P., Pachur, H.-J., 1999. Simulation of an abrupt change in Saharan vegetation in the mid-Holocene. Geophysical Research Letters 26, 2037-2040.

Cullen, H.M., deMenocal, P.B., Hemming, S., Hemming, G., Brown, F.H., Guilderson, T., Sirocko, F., 2000. Climate change and the collapse of the Akkadian empire: evidence from the deep sea. Geology 28, 379-382.

deMenocal, P., Ortiz, J., Guilderson, T., Adkins, J., Sarnthein, M., Baker, L., Yarusinsky, M., 2000. Abrupt onset and termination of the African Humid Period: rapid responses to gradual insolation forcing. Quaternary Science Reviews 19, 347-361.

Ducassou, E., Mulder, T., Migeon, S., Gonthier, E., Murat, A., Revel, M., Capotondi, L., Bernasconi, S.M., Mascle, J., Zaragosi, S., 2008. Nile floods recorded in deep Mediterranean sediments. Quaternary Research 70, 382-391.

Ducassou, E., Migeon, S., Mulder, T., Murat, A., Capotondi, L., Bernasconi, M., Mascle, J., 2009. Evolution of the Nile deep-sea turbidite system during the late Quaternary: influence of climate change on fan sedimentation. Sedimentology 56, 2061-2090.

Fairbanks, R.G., Mortlock, R.A., Chiu, T.-C., Cao, L., Kaplan, A., Guilderson, T.P., Fairbanks, T.W., Bloom, A.L., Grootes, P.M., Nadeau, M.-J., 2005. Marine radiocarbon calibration curve spanning 0 to 50,000 years B.P. Based on paired $230 \mathrm{Th} /$ $234 \mathrm{U} / 238 \mathrm{U}$ and $14 \mathrm{C}$ dates on pristine corals. Quaternary Science Reviews 24, $1781-1796$.

Faure, H., 1969. Lacs quaternaires du Sahara. Internationale Vereinigung für theoretische und angewandte Limnologie. Mitteilung 17, 131-146.

Faure, H., Manguin, E., Nydal, R., 1963. Formations lacustres du Quaternaire supérieur du Niger oriental: Diatomites et âges absolus. Bulletin du Bureau de Recherches géologiques et minières (Dakar) 3, 41-63.

Fontes, J.-C., Gasse, F., Callot, Y., Plaziat, J.-C., Carbonel, P., Dupeuple, P.-A., Kaczmarska, I., 1985. Freshwater to marine-like environments from Holocene lakes in Northern Sahara. Nature 317, 608-610.

Freydier, R., Michard, A., De Lange, G., Thomson, J., 2001. Nd isotopic compositions of eastern Mediterranean sediments: tracers of the Nile influence during sapropel S1 formation. Marine Geology 177, 45-62.

Frumkin, A. 2009. Stable isotopes of a subfossil Tamarix tree from the Dead Sea region, Israel, and their implications for the Intermediate Bronze Age environmental crisis. Quaternary Research 71, 319-328.

Gasse, F., 2000. Hydrological changes in the African tropics since the last glacial maximum. Quaternary Science Reviews 19, 189-211.

Gasse, F., Chalié, F., Vincens, A., Williams, M.A.J., Williamson, D., 2008. Climatic patterns in equatorial and southern Africa from 30,000 to 10,000 years ago reconstructed from terrestrial and near-shore proxy data. Quaternary Science Reviews 27, 2316-2340.

Grove, A.T., 1958. The ancient erg of Hausaland and similar formations on the south side of the Sahara. Geographical Journal 124, 528-533.

Grove, A.T., 1980. Geomorphic evolution of the Sahara and the Nile. In: Williams, M.A.J., Faure, H. (Eds.), The Sahara and the Nile. A.A. Balkema, Rotterdam, pp. 7-16.

Grove, A.T., 1993. Africa's climate in the Holocene. In: Shaw, T., Sinclair, P., Andah, B., Okpoko, A. (Eds.), The Archaeology of Africa: Food, Metals and Towns. Routledge, London, pp. 32-42.
Grove, A.T., Warren, A., 1968. Quaternary landforms and climate on the south side of the Sahara. Geographical Journal 134, 194-208.

Gunn, R.H., 1982. The plains of the central and southern Sudan. In: Williams, M.A.J., Adamson, D.A. (Eds.), A Land between Two Niles: Quaternary Geology and Biology of the Central Sudan. A.A. Balkema, Rotterdam, pp. 81-109.

Guo, Z., Petit-Maire, N., Kröpelin, S., 2000. Holocene non-orbital climatic events in present-day arid areas of northern Africa and China. Global and Planetary Change 26, 97-103.

Hassan, F.A., 1997. Holocene palaeoclimates of Africa. African Archaeological Review $14,213-230$

Hassan, F.A., Barich, B., Mahmoud, M., Hemdan, M.A., 2001. Holocene playa deposits of Farafra Oasis, Egypt, and their palaeoclimatic and geoarchaeological significance. Geoarchaeology 16, 29-44.

Higgs, N.C., Thomson, J., Wilson, T.R.S., Croudace, I.W., 1994. Modification and complete removal of eastern Mediterranean sapropels by postdepositional oxidation. Geology 22, 423-426.

Hoelzmann, P., 1993a. Holozäne Limnite im NW-Sudan. Ph.D. thesis, Freie Universität, Berlin, pp. 1-191.

Hoelzmann, P., 1993b. Palaeoecology of Holocene lacustrine sediments in Western Nubia, SE Sahara. In: Thorweihe, U., Schandelmeier, H. (Eds.), Geoscientific Research in Northeast Africa. A.A. Balkema, Rotterdam, pp. 569-574.

Hoelzmann, P. Jolly, D., Harrison, S.P., Laarif, F., Bonnefille, R., Pachur, H.-J., 1998. Mid-Holocene land-surface conditions in northern Africa and the Arabian Peninsula: a data set for the analysis of biogeophysical feedbacks in the climate system. Global Biogeochemical Cycles 12, 35-51.

Hoelzmann, P., Kruse, H.-J., Rottinger, F., 2000. Precipitation estimates for the eastern Saharan palaeomonsoon based on a water balance model of the West Nubian Palaeolake basin. Global and Planetary Change 26, 105-120.

Hoelzmann, P., Keding, B., Berke, H., Kropelin, S., Kruse, H.-J., 2001. Environmental change and archaeology: lake evolution and human occupation in the Eastern Sahara during the Holocene. Palaeogeography, Palaeoclimatology, Palaeoecology $169,193-217$.

Hoelzmann, P., Gasse, F., Dupont, L.M., Salzmann, U., Staubwasser, M., Leuschner, D.C., Sirocko, F., 2004. Palaeoenvironmental changes in the arid and subarid belt (Sahara-Sahel-Arabian Peninsula) from 150 kyr to present. In: Battarbee, R.W., Gasse, F., Stickley, C.E. (Eds.), Past Climate Variability through Europe and Africa, vol. 6. Springer, Dordrecht, pp. 219-256.

Hötzel, G., Croome, R., 1996. Population dynamics of Aulacoseira granulata (Ehr.) Simonson (Bacillariophyceae, Centrales), the dominant alga in the Murray River, Australia. Archiv für Hydrobiologie 136, 191-215.

Hunting Technical Services Limited, 1964. The White Nile East Bank, Rabak to Khartoum: Soils and Engineering Reconnaissance. Roseires Soil Survey Report No. 6, 1-128. Ministry of Agriculture, Khartoum.

Hurni, H., 1982. Hochgebirge von Semien - Äthiopien. In: Klima und Dynamik der Höhenstufung von der letzten Kaltzeit bis zur Gegenwart, vol. II. Geographica Bernensia G 13, Beiheft 7 zum Jahrbuch der Geographischen Gesellschaft von Bern. 196.

Jahns, S., 1995. A Holocene pollen diagram from El Atrun, northern Sudan. Vegetation History and Archaeobotany 4, 23-30.

Johnson, T.C., Kelts, K., Odada, E., 2000. The Holocene history of Lake Victoria. Ambio 29, 2-11.

Johnson, T.C., Scholz, C.A., Talbot, M.R., Kelts, K., Ricketts, R.D., Ngobi, G., Beuning, K., Ssemmanda, I., McGill, J.W., 1996. Late Pleistocene desiccation of Lake Victoria and rapid evolution of cichlid fishes. Science 273, 1091-1093.

Jousse, H., 2004. Impact des variations environnementales sur la structure des communautés mammaliennes et l'anthropisation des milieux: Exemple des faunes holocènes du Sahara occidental. Documents du Laboratoire de Géologie. Université Claude Bernard-Lyon, 1, No. 160, 273 pp.

Kieniewicz, J.M., Smith, J.R., 2007. Hydrologic and climatic implications of stable isotope and minor element analyses of authigenic calcite silts and gastropod shells from a mid-Pleistocene pluvial lake, Western Desert, Egypt. Quaternary Research 68, 431-444.

Krom, M.D., Stanley, D., Cliff, R.A., Woodward, J.C., 2002. River Nile sediment fluctuations over the past $7000 \mathrm{yr}$ and their key role in sapropel development. Geology 30, 71-74.

Kröpelin, S., 1993. Zur Rekonstruktion der spätquartären Umwelt am Unteren Wadi Howar (Südöstliche Sahara/NW Sudan). Berliner Geographische Abhandlungen 54, 1-193.

Kuper, R., Kröpelin, S., 2006. Climate-controlled Holocene occupation of the Sahara: motor of Africa's evolution. Science 313, 803-807.

Kutzbach, J.E., Street-Perrott, F.A., 1985. Milankovitch forcing of fluctuations in the level of tropical lakes from 18 to 0 kyr BP. Nature 317, 130-134.

Lamb, H.F., Bates, C.R., Coombes, P.V., Marshall, M.H., Umer, M., Davies, S.J., Dejen, E., 2007. Late Pleistocene desiccation of Lake Tana, source of the Blue Nile. Quaternary Science Reviews 26, 287-299.

Larrasoaňa, J.C., Roberts, A.P., Rohling, E.J., Winklhofer, M., Wehausen, R., 2003. Three million years of monsoon variability over the northern Sahara. Climate Dynamics 21, 689-698.

Leier, A.L., DeCelles, P.G., Pelletier, J.D., 2005. Mountains, monsoons and megafans. Geology 33, 289-292.

Linstädter, J., Kröpelin, S., 2004. Wadi Bakht revisited: Holocene climate change and prehistoric occupation in the Gilf Kebir region of the Eastern Sahara, SW Egypt. Geoarchaeology 19, 753-778.

Lourens, L.J., Antonarakou, A., Hilgen, F.J., Van Hoof, A.A.M., Vergnaud-Grazzini, C., Zachariasse, W.J., 1996. Evaluation of the Plio-Pleistocene astronomical timescale. Paleoceanography 11, 391-413. 
Lærdal, T., Talbot, M.R., Russell, J.M., 2002. Late Quaternary sedimentation and climate in the lakes Edward and George area, Uganda-Congo. In: Odada, E.O., Olago, D.O. (Eds.), The East African Great Lakes: Limnology, Palaeolimnology and Biodiversity. Kluwer, Dordrecht, pp. 429-470.

Mainguet, M., Canon, L., Chemin, M.C., 1980. Le Sahara: geomorphologie et paleogeomorphologie éoliennes. In: Williams, M.A.J., Faure, H. (Eds.), The Sahara and the Nile. A.A. Balkema, Rotterdam, pp. 17-35.

Maley, J., 2000. Last Glacial Maximum lacustrine and fluviatile formations in the Tibesti and other Saharan mountains, and large-scale climatic teleconnections linked to the activity of the Subtropical Jet Stream. Global and Planetary Change 26, 121-136.

Maley, J., 2004. Le bassin du Tchad au Quaternaire récent: formations sédimentaires, paléoenvironnements et préhistoire. La question des Paléotchads. In: Renault-Miskovsky, J., Semah, A.-M. (Eds.), Guide de la Préhistoire mondiale. Artcom, Paris, pp. 179-217.

Mawson, R., Williams, M.A.J., 1984. A wetter climate in eastern Sudan 2000 years ago? Nature 309, 49-51.

Mayewski, P.A., Rohling, E.E., Stager, J.C., Karlén, W., Maasch, K.A., Meeker, L.D. Meyerson, E.A., Gasse, F., Van Kreveld, S., Lee-Thorp, J., Rosqvist, G., Rack, F., Staubwasser, M., Schneider, R.R., Steig, E.J., 2004. Holocene climate variability. Quaternary Research 62, 243-255.

Mercone, D., Thomson, J., Abu-Zied, R.H., Croudace, I.W., Rohling, E.J., 2001. Highresolution geochemical and micropalaeontological profiling of the most recent eastern Mediterranean sapropel. Marine Geology 177, 25-44

Mix, A.C., Bard, E., Schneider, R., 2001. Environmental processes of the ice age: land, oceans, glaciers (EPILOG). Quaternary Science Reviews 20, 627-657.

Mulitza, S., Rühlemann, C., 2000. African monsoonal precipitation modulated by interhemispheric temperature gradients. Quaternary Research 53, 270-274.

Murray, A.S., Wintle, A.G., 2000. Luminescence dating of quartz using an improved single-aliquot regenerative dose protocol. Radiation Measurements 32, 57-73.

Nanson, G.C., Knighton, A.D., 1996. Anabranching rivers: their cause, character and classification. Earth Surface Processes and Landforms 21, 217-239.

Ngomanda, A., Neumann, K., Schweizer, A., Maley, J., 2009. Seasonality change and the third millennium BP rainforest crisis in southern Cameroon (Central Africa) Quaternary Research 71, 307-318.

Nichol, J.E., 1991. The extent of desert dunes in northern Nigeria as shown by image enhancement. Geographical Journal 157, 13-24.

Nichol, J.E., 1999. Geomorphological evidence and Pleistocene refugia in Africa. Geographical Journal 165, 79-89.

Osmaston, H.A., Mitchell, W.A., Osmaston, J.A.N., 2005. Quaternary glaciation of the Bale Mountains, Ethiopia. Journal of Quaternary Science 20, 593-606.

Pachur, H.-J., Altmann, N., 1997. The Quaternary (Holocene, ca. 8000a BP). In: Schandelmeier, H., Reynolds, P.-O. (Eds.), Palaeogeographic-Palaeotectonic Atlas of North-Eastern Africa, Arabia and Adjacent Areas: Late Neoproterozoic to Holocene. A.A. Balkema, Rotterdam, pp. 111-125.

Pachur, H.-J., Hoelzmann, P., 1991. Paleoclimatic implications of late Quaternary lacustrine sediments in Western Nubia, Sudan. Quaternary Research 36 257-276.

Pachur, H.-J., Hoelzmann, P., 2000. Late Quaternary palaeoecology and palaeoclimates of the Eastern Sahara. Journal of African Earth Sciences 30, 029-939.

Pachur, H.-J., Kröpelin, S., Hoelzmann, P., Goschin, M., Altmann, N., 1990. Late Quaternary fluvio-lacustrine environments of western Nubia. Berliner Geowissentschaftliche Abhandlungen (A) 120 (1), 203-260.

Pachur, H.-J., Wünnemann, B., 1996. Reconstruction of the palaeoclimate along $30^{\circ} \mathrm{E}$ in the eastern Sahara during the Pleistocene/Holocene transition. Palaeoecology of Africa 24, 1-32.

Prentice, I.C., Jolly, D., BIOME 6000 participants, 2000. Mid-Holocene and glacialmaximum vegetation geography of the northern continents and Africa. Journal of Biogeography 27, 507-519.

Prescott, J.R., Hutton, J.T., 1994. Cosmic ray contribution to dose rates for luminescence and ESR dating: large depths and long-term variations. Radiation Measurements 23, 497-500.

Prescott, J.R., Williams, F.M., Hunt, C.D., 2007. Comparison of TL multiple aliquot, single grain GLSL SAR and C-14 ages for the Puritjarra, Australia, rock shelter. Quaternary Geochronology 2, 344-349.

Reid, M.A., Ogden, R.W., 2009. Factors affecting the distribution of diatoms in billabong surface sediments from the Murray Basin, southeastern Australia. Journal of Paleolimnology 41, 453-470.

Ritchie, J.C., Eyles, C.H., Haynes, C.V., 1985. Sediment and pollen evidence for an early to mid-Holocene humid period in the eastern Sudan. Nature 314, 352-355.

Rossignol-Strick, M., 1985. Mediterranean Quaternary sapropels, an immediate response of the African monsoon to variations in insolation. Palaeogeography, Palaeoclimatology, Palaeoecology 49, 237-263.

Rossignol-Strick, M., 1999. The Holocene climatic optimum and pollen records of sapropel 1 in the eastern Mediterranean, 9000-6000 BP. Quaternary Science Reviews 18, 515-530.

Rossignol-Strick, M., Nesterhoff, W., Olive, P., Vergnaud-Grazzini, C., 1982. After the deluge: Mediterranean stagnation and sapropel formation. Nature 295 105-110.

Salzmann, U., Hoelzmann, P., Morczinek, I., 2002. Late Quaternary climate and vegetation of the Sudanian zone of northeast Nigeria. Quaternary Research 58, 73-83.

Schild, R., Wendorf, F., 2001. Geoarchaeology of the Holocene climatic optimum at Nabta playa, Southwestern desert, Egypt. Geoarchaeology 16, 7-28.

Schulz, E., 1994. The southern limit of the Mediterranean vegetation in the Sahara during the Holocene. Historical Biology 9, 137-156.
Scrivner, A.E., Vance, D., Rohling, E.J., 2004. New neodymium isotope data quantify Nile involvement in Mediterranean anoxic episodes. Geology 32, 565-568.

Sir Alexander Gibb \& Partners, 1954. Estimation of Irrigable Areas in the Sudan 1951-3: Report to the Sudan Government. Metcalf and Cooper Ltd., London.

Stager, J.C., Cumming, B., Meeker, L., 1997. A high-resolution 11,400-yr diatom record from lake Victoria, East Africa. Quaternary Research 47, 81-89.

Stager, J.C., Cumming, B.F., Meeker, L.D., 2003. A 10,000-year high-resolution diatom record from Pilkington Bay, lake Victoria, east Africa. Quaternary Research 59, $172-181$.

Stager, J.C., Johnson, T.C., 2000. A $12,400{ }^{14} \mathrm{C}$ yr offshore diatom record from eas central Lake Victoria, East Africa. Journal of Paleolimnology 23, 373-383.

Stager, J.C., Johnson, T.C., 2008. The Late Pleistocene desiccation of Lake Victoria and the origin of its endemic biota. Hydrobiologia 596, 5-16.

Stager, J.C., Mayewski, P.A., Meeker, L.D., 2002. Cooling cycles, Heinrich event 1, and the desiccation of Lake Victoria. Palaeogeography, Palaeoclimatology, Palaeoecology 183, 169-178.

Stager, J.C., Reinthal, P.N., Livingstone, D.A., 1986. A 25,000-year history for Lake Victoria, East Africa, and some comments on its significance for the evolution of cichlid fishes. Freshwater Biology 16, 15-19.

Stanley, J.-D., Krom, M.D., Cliff, R.A., Woodward, J.A., 2003. Nile flow failure at the end of the Old Kingdom, Egypt: strontium isotopic and petrologic evidence. Geoarchaeology 18, 395-402.

Swezey, C., 2001. Eolian sediment responses to late Quaternary climate changes: temporal and spatial patterns in the Sahara. Palaeogeography, Palaeoclimatology, Palaeoecology 167, 119-155.

Talbot, M.R., 1980. Environmental responses to climatic change in the West African Sahel over the past 20000 years. In: Williams, M.A.J., Faure, H. (Eds.), The Sahara and the Nile. A.A. Balkema, Rotterdam, pp. 37-62.

Talbot, M.R., Williams, M.A.J., 2009. Cenozoic evolution of the Nile basin. In Dumont, H.J. (Ed.), The Nile: Origin, Environments, Limnology and Human Use. Springer Science/Business Media B.V, pp. 37-60.

Talbot, M.R., Williams, M.A.J., Adamson, D.A., 2000. Strontium isotope evidence for late Pleistocene reestablishment of an integrated Nile drainage network Geology 28, 343-346.

Tibby, J., Reid, M., 2004. A model for inferring past conductivity in low salinity waters derived from Murray River diatom plankton. Marine and Freshwater Research 55, 587-607.

Tzedakis, P.C., 2009. Cenozoic climate and vegetation change. In: Woodward, J.C. (Ed.), The Physical Geography of the Mediterranean. Oxford University Press, Oxford, pp. 89-137.

Verschuren, D., Jaap, S., Sinninghe Damsté, J.S., Moernaut, J., Kristen, I., Blaauw, M., Fagot, M., Haug, G.H., CHALLACEA project members, 2009. Half-precessional dynamics of monsoon rainfall near the East African equator. Nature 462 637-641.

Welsby, D.A., Macklin, M.G., Woodward, J.C., 2002. Human responses to Holocene environmental changes in the northern Dongola reach of the Nile. In: Friedman, R. (Ed.), Egypt and Nubia: Gifts of the Desert. British Museum Press, London, pp. 28-41.

Willcocks, W., 1904. The Nile in 1904. E. \& F.N. Spon, London, 225 pp..

Williams, M.A.J., 1966. Age of alluvial clays in the western Gezira, Republic of the Sudan. Nature 211, 270-271.

Williams, M.A.J., 1968. A dune catena on the clay plains of the west central Gezira, Republic of the Sudan. Journal of Soil Science 19, 367-378.

Williams, M.A.J., 2009. Late Pleistocene and Holocene environments in the Nile basin. Global and Planetary Change 69,1-15.

Williams, M.A.J., Abell, P.I., Sparks, B.W., 1987. Quaternary landforms, sediments, depositional environments and gastropod isotope ratios at Adrar Bous, Tenere Desert of Niger, south-central Sahara. In: Frostick, L., Reid, I. (Eds.), Desert Sediments: Ancient and Modern. Geological Society Special Publication No. 35, pp. 105-125.

Williams, M.A.J., Adamson, D.A., 1974. Late Pleistocene desiccation along the White Nile. Nature 248, 584-586.

Williams, M.A.J., Adamson, D.A., 1980. Late Quaternary depositional history of the Blue and White Nile rivers in central Sudan. In: Williams, M.A.J., Faure, H. (Eds.), The Sahara and the Nile. A.A.Balkema, Rotterdam, pp. 281-304.

Williams, M.A.J., Adamson, D.A., Abdulla, H.H., 1982. Landforms and soils of the Gezira: a Quaternary legacy of the Blue and White Nile rivers. In: Williams, M.A.J., Adamson, D.A. (Eds.), A Land Between Two Niles. Quaternary Geology and Biology of the Central Sudan. A.A. Balkema, Rotterdam, pp. $111-142$.

Williams, M.A.J., Adamson, D., Cock, B., McEvedy, R., 2000. Late Quaternary environments in the White Nile region, Sudan. Global and Planetary Change 26 305-316.

Williams, M.A.J., Adamson, D., Prescott, J.R., Williams, F.M., 2003. New light on the age of the White Nile. Geology 31, 1001-1004

Williams, M.A.J., Adamson, D.A., Williams, F.M., Morton, W.H., Parry, D.E., 1980. Jebe Marra volcano: a link between the Nile valley, the Sahara and central Africa. In: Williams, M.A.J., Faure, H. (Eds.), The Sahara and the Nile. A.A. Balkema, Rotterdam, pp. 305-337.

Williams, M., Cook, E., van der Kaars, S., Barrows, T., Shulmeister, J., Kershaw, P., 2009. Glacial and deglacial climatic patterns in Australia and surrounding regions from 35000 to 10000 years ago reconstructed from terrestrial and near-shore proxy data. Quaternary Science Reviews 28, 2398-2419.

Williams, M.A.J., Medani, A.H., Talent, J.A., Mawson, R., 1974. A note on upper Quaternary mollusca west of Jebel Aulia. Sudan Notes and Records 54, 168-172. 
Williams, M.A.J., Street, F.A., Dakin, F.M., 1978. Fossil periglacial deposits in the Semien Highlands, Ethiopia. Erdkunde 32, 40-46.

Williams, M.A.J., Talbot, M.R., 2009. Late Quaternary environments in the Nile basin. In: Dumont, H.J. (Ed.), The Nile: Origin, Environments, Limnology and Human Use. Springer Science/Business Media B.V, pp. 61-71.

Williams, M., Talbot, M., Aharon, P., Abdl Salaam, Y., Williams, F., Brendeland, K.I., 2006. Abrupt return of the summer monsoon 15,000 years ago: new supporting evidence from the lower White Nile valley and Lake Albert. Quaternary Science Reviews 25, 2651-2665.
Woodward, J.C., Macklin, M.G., Welsby, D., 2001. The Holocene fluvial sedimentary record and alluvial geoarchaeology in the Nile valley of northern Sudan. In: Maddy, D.R., Macklin, M.G., Woodward, J.C. (Eds.), River Basin Sediment Systems: Archives of Environmental Change. A.A. Balkema, Rotterdam, pp. 327-355.

Woodward, J.C., Macklin, M.G., Krom, M.D., Williams, M.A.J., 2007. The Nile: evolution, Quaternary river environments and material fluxes. In: Gupta, A. (Ed.), Large Rivers: Geomorphology and Management. John Wiley \& Sons, Chichester, pp. 261-292. 